\title{
Natural vs Anthropogenic Streams in Europe: History, Ecology and Implications for Restoration, River-Rewilding and Riverine Ecosystem Services
}

\author{
Antony G Brown ${ }^{\mathrm{a},{ }^{*} \text {, Laurent Lespez }}{ }^{\mathrm{b}}$, David A Seara, Jean-Jacques Macairec, Peter Houben ${ }^{\mathrm{d}}$, \\ Kazimierz Klimek ${ }^{\mathrm{e}}$, Richard E Brazier ${ }^{\mathrm{f}}$, Kristof Van Oost ${ }^{\mathrm{g}}$, Ben Pears ${ }^{\mathrm{a}}$ \\ a Geography \& Environment, University of Southampton, Shackleton Building, Southampton SO17 1BJ UK. \\ Tony.Brown@soton.ac.uk, D.Sear @soton.ac.uk \\ b Laboratory of Physical Geography (LGP) CNRS-UMR 8591, University of Paris-East Créteil, France. \\ laurent.lespez@lgp.cnrs.fr \\ c Department of Science and Techniques, Universite de Tours, Parc de Grandmont 37200, Tours, FrFrance, \\ jean-jacques.macaire@univ-tours.fr \\ ${ }^{\mathrm{d}}$ Environmental Earth Science and Sustainability, Leiden University College - The Hague, Netherlands \\ p.houben@luc.leidenuniv.nl \\ e Department of Physical Geography, Earth Science Faculty, University of Silesia, Będzińska 60, 41-200 \\ Sosnowiec, Poland, klimek@ultra.cto.us.edu.pl \\ ${ }^{f}$ Geography, College of Life and Environmental Sciences, University of Exeter, Exeter EX44RJ, UK. \\ r.e.brazier@exeter.ac.uk \\ ${ }^{\mathrm{g}}$ Earth and Life Institut, Université Catholique de Louvain, Louvain-la-Neuve, Belgium \\ * corresponding author Email address Tony.Brown@soton.ac.uk
}




\section{ABSTRACT}

In Europe and North America the prevailing model of 'natural' lowland streams is incisedmeandering channels with silt-clay floodplains, and this is the typical template for stream restoration. Using both published and new unpublished geological and historical data from Europe we critically review this model, show how it is inappropriate for the European context, and examine the implications for carbon sequestration and Riverine Ecosystem Services (RES) including river rewilding. This paper brings together for the first time, all the pertinent strands of evidence we now have on the long-term trajectories of floodplain system from sediment-based dating to sedaDNA. Floodplain chronostratigraphy shows that early Holocene streams were predominantly multichannel (anabranching) systems, often choked with vegetation and relatively rarely single-channel actively meandering systems. Floodplains were either non-existent or limited to adjacent organicfilled palaeochannels, spring/valley mires and flushes. This applied to many, if not most, small to medium rivers but also major sections of the larger rivers such as the Thames, Seine, Rhône, Lower Rhine, Vistula and Danube. As shown by radiocarbon and optically stimulated luminescence (OSL) dating during the mid-late Holocene c. 4-2ka BP, overbank silt-clay deposition transformed European floodplains, covering former wetlands and silting-up secondary channels. This was followed by direct intervention in the Medieval period incorporating weir and mill-based systems part of a deep engagement with rivers and floodplains which is even reflected in river and floodplain settlement place names. The final transformation was the 'industrialisation of channels' through hard-engineering - part of the Anthropocene great acceleration. The primary causative factor in transforming pristine floodplains was accelerated soil erosion caused by deforestation and arable farming, but with effective sediment delivery also reflecting climatic fluctuations. Later floodplain modifications built on these transformed floodplain topographies. So, unlike North America where channel-floodplain transformation was rapid, the transformation of European streams occurred over a much longer time-period with considerable spatial diversity regarding timing and kind of modification. This has had implications for the evolution of RES including reduced carbon sequestration over the past millenia. Due to the multi-faceted combination of catchment controls, ecological change and cultural legacy, it is impractical, if not impossible, to identify an originally natural condition and thus restore European rivers to their pre-transformation state (naturalisation). Nevertheless, attempts to restore to historical (pre-industrial) states allowing for natural floodplain processes can have both ecological and carbon offset benefits, as well as additional abiotic benefits such as flood attenuation and water quality improvements. This includes rewilding using beaver reintroduction which has overall positive benefits on river corridor ecology. New developments, particularly biomolecular methods offer the potential of unifying modern ecological monitoring with reconstruction of past ecosystems and their trajectories. The sustainable restoration of rivers and floodplains designed to maximise desirable RES and natural capital must be predicated on the awareness that Anthropocene rivers are still largely imprisoned in the banks of their history and this requires acceptance of an increased complexity for the achievement and maintenance of desirable restoration goals. 


\section{Introduction: stream engineering and natural reference conditions}

For decades meandering, gravel-bedded, streams with fine-grained floodplains forming their banks have been considered as a universal model explaining the morphology and functioning of natural streams in temperate lowland temperate European and North American riverine landscapes (Leopold and Wolman, 1957; Wolman and Leopold, 1957). As a logical consequence, the concept has also served as template for natural reference conditions (RRC, 2001; Kondolf, 2006). The morphological evolution of these channels is typically modelled through shear stress-fields dependant largely upon topographic-steer driven by the alternation of pool and riffles in equilibrium with radii of bend curvature and stream width (De Moor et al., 2007). This perception and model is increasingly challenged as initially similar-looking stream-floodplain morphologies may involve a considerable variety of inherited floodplain-building processes. This applies even more so when the millennia-long record of human interference has been interwoven into what we might perceive as classic river landscapes.

The floodplains of European lowland streams are characteristically of very low relief (1-2 m) and typically less than channel depth (1-4 m) as revealed by LIDAR surveys (Mann et al., 2007). The principal cause is Holocene overbank sedimentation of sand, silt and clay (Brown and Barber, 1986; Dotterweich, 2008; Pastre et al., 2001; Lespez et al., 2008; Macklin et al., 2010; Broothaerts et al., 2012; Brown et al., 2013; Macklin et al., 2014). It is often an idealised fluvial ensemble of floodplain flats, low or no levées, and sinuous (meandering) stream form to which channels are currently being restored in Europe with the re-engineering of meanders, pools and riffles (Moss and Monsadt, 2008). Studies of alluvial floodplains in geological sections suggest that fixed-channel anabranching or anastomosing channel forms are associated with fully vegetated floodplains from the Carboniferous Period onwards (Davies and Gibling, 2011). The popularity of the high-sinuosity single-channel form may owe something to the cultural perception of the tranquil meandering of rivers (form rather than the process, or in ecological terms the structure rather than the function) so commonly depicted in both art and literature - a common European aesthetic of perceived naturalness - the serpentine form as exemplified by the English $19^{\text {th }}$ Century landscape painter Constable, and others (Kondolf, 2006). In addition, further important goals of river restoration concern the desire to increase biodiversity and ecosystem functioning through attaining 'natural' and sustainable floodplain landscapes. High levels of uncertainty are commonly attached to river restoration outcomes (Darby and Sear, 2008) and as this paper shows in Europe this is due to 
complexity created by inherited elements derived from their Holocene evolution and a much more prolonged and gradual transformation of European rivers in comparison to the abrupt transformation of rivers in Australia and the Americas (Brierley et al., 2005). The abrupt New World transformations, were in some cases associated with mills and dams (Walter and Merritts, 2008), or large changes in sediment supply (Happ et al., 1940; Trimble, 1981). These changes occurred in all climatic zones including the semi-arid zone, where anastomosing systems were transformed in under 200 years (Florsheim and Mount 2003: Florsheim et al., 2008) with implications for flood hazard (Florsheim et al. (2011).

In Europe expenditure on river, enhancement, rehabilitation and restoration is significant and is usually by the State or local authorities, and ultimately the taxpayer. The current annual spend is at the very minimum $£ 6-10 \mathrm{M}$ (\$US 7.7 M - 12.8 M) in England (DEFRA, 2015), and as much as \$US 4.2 billion in Germany (Ecologic Institute, 2016). There have now been over 500 schemes completed in France alone (Dolédec et al., 2015), and the annual expenditure by the Water Agencies, which are the main funders of the ecological resstoration of river and wetland in France (Morandi and Piegay, 2016), is around $180 \mathrm{M}$ euros per year for their 10th program of intervention covering the 20132018 period (Annex of the Finance Act 2017). With over 2000 schemes, 110 involving remeandering Denmark leads the way in river restoration or rehabilitation with varying ecological results (Madson and Debois, 2005; Pedersen et al., 2014). Social research from Switzerland, where the residents of Bern Canton voted to spend $3 \mathrm{M}$ Swiss francs (\$US $3.1 \mathrm{M}$ ) annually on river restoration, suggests that such expenditure has public support (Schläpfer and Witzig, 2006). Unfortunately no total figures are available centrally but a minimum of \$US 8-10 billion for the European Union in total can be estimated using German costs of between $0.5 \mathrm{M}-1 \mathrm{M}$ Euros per km excluding land acquisition (Morandi and Piégay, 2011). Global expenditure has been estimated at approximately \$US 3 billion annually (Roni and Beech, 2013). 
In North America the classic view of channel form and floodplain morphology (Leopold and Wolman, 1957) has been challenged by the proposition that for mid-Atlantic and western streams,

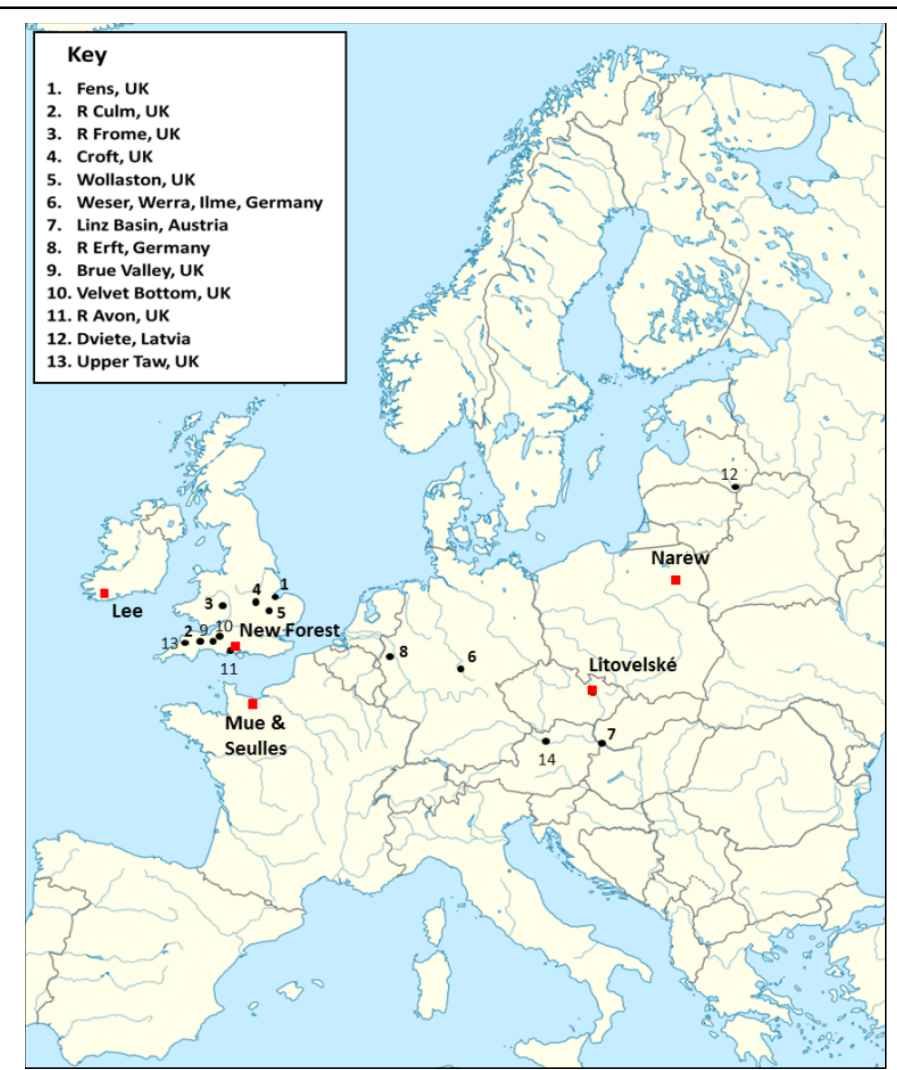

Fig. 1 Map of Europe showing the case study areas (red squares) and other sites mentioned in the text.

form is largely a legacy of the impoundment of the valley floors by water-powered mills (Walter and Merritts, 2008; Merritts et al., 2011). This places short- to mid-term channel and floodplain form in a historic context where the evolution of valley-flats, and more recent incised meandering channels, are temporally decoupled and respond to direct, and abrupt, human impact without any buffering from floodplain environments. These conclusions also pose questions for the formative definition of the morphology and sustained functioning of natural channel-floodplain environments that underlie most channel restoration projects. It has further been proposed that a similar alluviation in temperate Europe might also have been the result of milldamming (Walter and Merritts, 2008; Houben et al., 2013).

In this paper we have pooled both published and unpublished data from across temperate Europe (Fig. 1) to test this proposition by charting floodplain transformation from natural Holocene conditions to the uncoupled state of channels and floodplains we observe today. We use geomorphological and palaeoecological data to examine the state of rivers and floodplains prior to and during their transformation by human activity, and discuss how this relates to river restoration and rewilding and the implications for both carbon sequestration and floodplain management. New techniques, such as biomolecular analyses, are also introduced that may greatly increase our ability to detail past floodplain ecology accurately and in depth. We develop this analysis to examine the possibility of returning floodplains to a prior, more connected multi-functional state (Schindler et al., 2016), with the implications this has for riverine ecosystem services (RES), river-rewilding (RRW) and implications for carbon sequestration within river corridors. RES in Europe has strong 
similarities with riverine ecosystems synthesis in North America (RES sensu Thorp et al, 2006) including the biodiversity and carbon sequestration potential of floodplain-channel systems (Lespez, 2013; 2015).

\section{Methods, materials and data sources}

The most fundamental data for the state of past rivers is contained within the physical and biological characteristics of their deposits. This paper uses radiocarbon and optically stimulated luminescence (OSL) dated floodplain stratigraphies. Additionally two novel data sources are introduced: the use of river and place names to investigate floodplain and river conditions about 1000 years ago and also biomolecular methods including sedaDNA. A deeper understanding of past riverine ecosystems allows us to as not only what elements of rewilding might achieve desired goals, but also, what elements of rewilding are possible or require substitution such as the role of extinct herbivores. We have assessed these questions, by collating the following bodies of evidence: (a) studies of early Holocene channel form from rivers prior to significant deforestation in their catchments, (b) studies of channel and floodplains in transition during the periods of maximum landscape change in most of Europe which is $3-0.5$ ka years BP - the European Late Bronze to Medieval Period (Section 3), (c) the density of channel obstructions and their implications for historical channel form (Sections 3- 5), (d) the ecological processes and biodiversity of the few remaining multi-channel systems through the case studies (Section 6), and lastly (e) carbon storage and sequestration of pre-transformation and modern channel-floodplains (Section 7). The future potential of biomolecular methods on fluvial sediments is outlined (Section 8) and rewilding projects are discussed in relation to their ecological and environmental goals (Section 9).

\section{Pre-deforestation channels and primary floodplain transformation.}

Although the Pleistocene to Holocene hydrological trajectories of larger European rivers are now well known from many studies of temperate palaeohydrology (Starkel et al., 1991; Gregory et al., 1995) the number of observations of pre-deforestation floodplain sequences for smaller systems ( $<5$ th order streams) is far lower than for later periods or for post-deforestation streams in Europe (Johnstone et al., 2006; Hoffmann et al., 2008). However, these studies do reveal that after a wellknown transition from braided and high-discharge conditions at the end of the Last Glacial Maximum (MIS 2) in northern areas, and the Pleniglacial in continental Europe, floodplains show either organic-rich palaeosols, peat or on carbonate lithologies - marl deposits (Baker and Sims, 
1998). Well known examples include the low-relief groundwater dominated catchments such as the Fens in England (French, 2003), Paris Basin, France (Pastre et al., 2001), the Netherlands and N

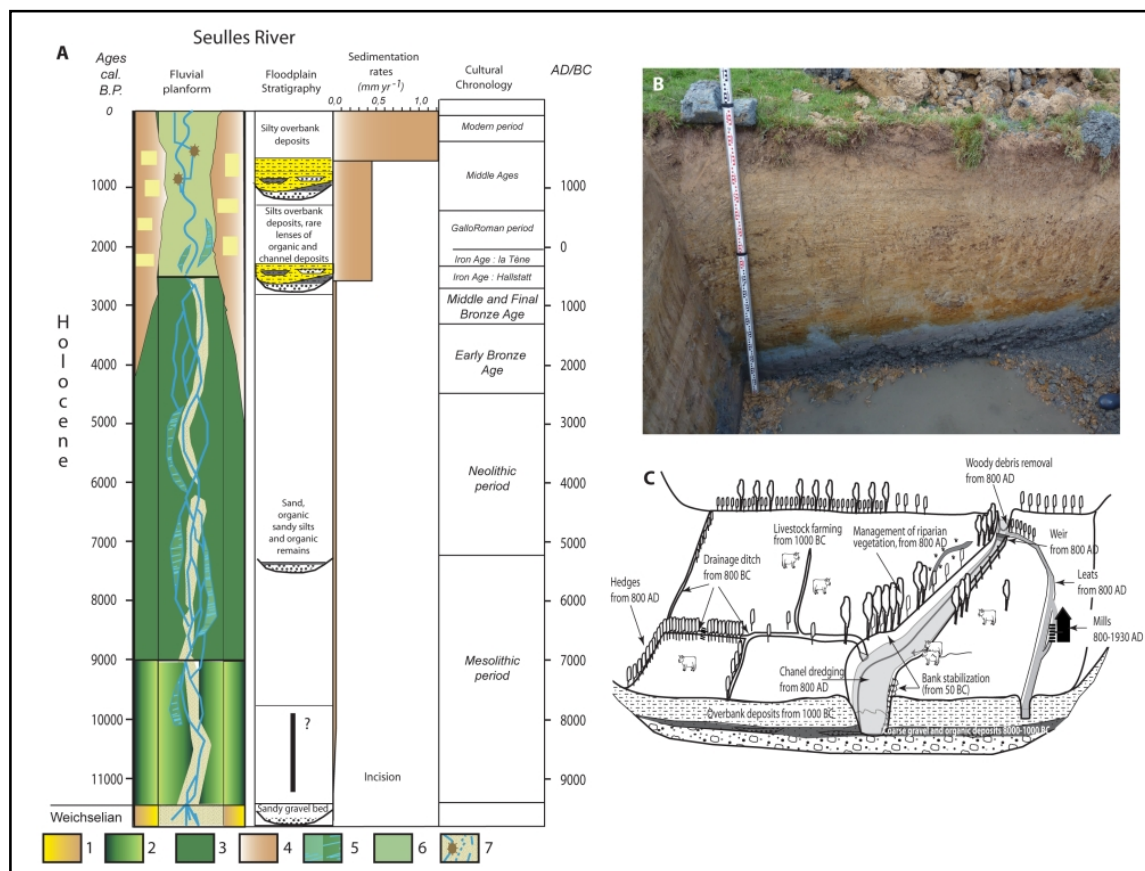

Fig. 2 Model of the Holocene development of Seulles river on the Normandy Plain.

Germany (Peeters, 2004; Behrendsen and Stouthamer, 2001; Boss, 2001). A study of the stratigraphy of the Mue and the Seulles River system in Normandy, France illustrates the different steps of 'natural' stream evolution (Lespez et al., 2008: 2015, Fig. 2). For the Mue river, as for numerous rivers from the Paris basin, sedimentation is mainly constituted by tuffaceous and/or organic sediments while the Seulles river, mainly flowing in the Armorican massif, experienced a prolonged period of organic sedimentation intercalated with sandy gravel lenses. We know from pollen and macrofossil diagrams from across temperate Europe that these early-mid Holocene floodplains were thickly-wooded with birch, willow, poplar and later alder and oak (Huntley and Birks, 1983; Brown, 1999; Dinnin and Brayshay, 1999; Lechner, 2009; Ejarque et al., 2015). Where there has been very limited subsequent overbank alluviation due to a lack of arable cultivation in the catchment this early-mid Holocene channel planform can be preserved. An example is the river Culm (Devon, UK) where mapping has revealed an anabranching pattern of palaeochannels, with channel abandonment and flow confinement to one or two channels due to the creation of cohesive riverbanks by overbank deposition only after land-enclosure in the $18^{\text {th }}$ century (Fig. 3a). More commonly such channel networks have been buried under metres of sand, silt and clay as is the case in the River Frome (Herefordshire, UK) where up to $5 \mathrm{~m}$ of overbank 
sediments has caused relative incision to the point where the floodplain has become a terrace with a channel width:depth ratio of 3-1 (typical average 1.2, Fig. 3b). Although sediment is transported by the flood series (Johnstone et al., 2011; Hoffmann et al., 2008), the fundamental cause of this accelerated alluviation is the coupling of erodible soils with intensified late Holocene arable cultivation. The result of this geomorphic history has been to transform the delivery of fine sediment through the floodplain with a lowering of floodplain groundwater table and in-channel storage initially predominating over overbank deposition (Collins and Walling, 2007), a conclusion first postulated in Germany as long ago as 1941 (Naterman, 1941). Excavations of small floodplains have revealed this transition from small often bifurcating channels with organic-rich floodplains to a silt-clay floodplain with a single channel, as exemplified here from Germany (Houben, 2007) and Central England (Fig. 4).

There are now enough OSL dates from European floodplains and particularly the UK so that it is

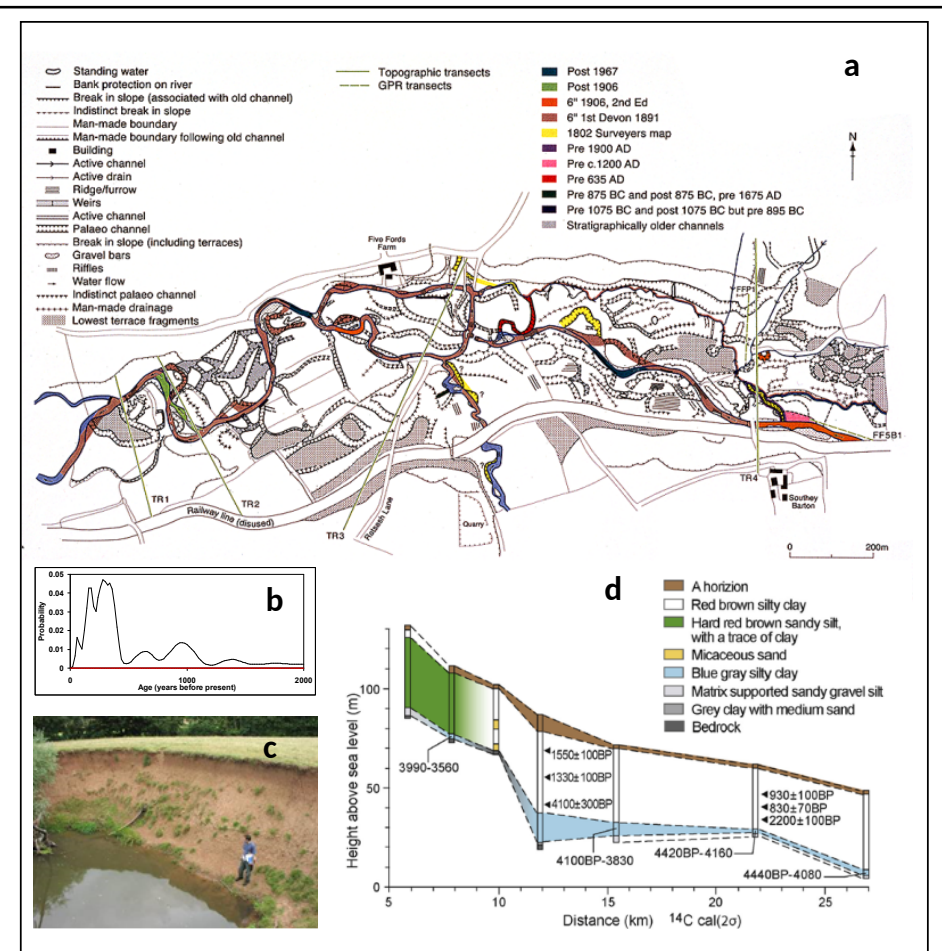

Fig. 3 (a) Anastomosing palaeochannels in a reach of the River Culm, SW England dated using 14C, OSL and documentary sources. (b) the frequency curve of overbank flooding from the OSL dates alone, (c) post-Bronze age (c. $3000 \mathrm{BP}$ ) superficial alluvial unit of the River Frome floodplain and (d) the longitudinal section of the River Frome (adapted from Brown et al.. 2013 ).

UK is contemporaneous and dates to the last 3000 years, and postdates the second major phase of perspective on floodplain sedimentation using direct sediment dating which can be compared to indirect sediment dating, mostly using radiocarbon. Fig. 5 illustrates the summed probability distribution (SPD) of the OSL dates of the superficial sedimentary unit (so-called buff-red silty clay member) in the Severn-Wye basin from 4 sites (Yarkhill in the Frome valley, Wasperton in the Avon valley and Buildwas and Clifton from the main Severn valley). The inset is the alluvial sequences from the UK with alluvial dates from Macklin et al. (2014) for comparison. What is clear is how the entire superficial overbank unit of the largest basin in the

possible to provide a Holocene 


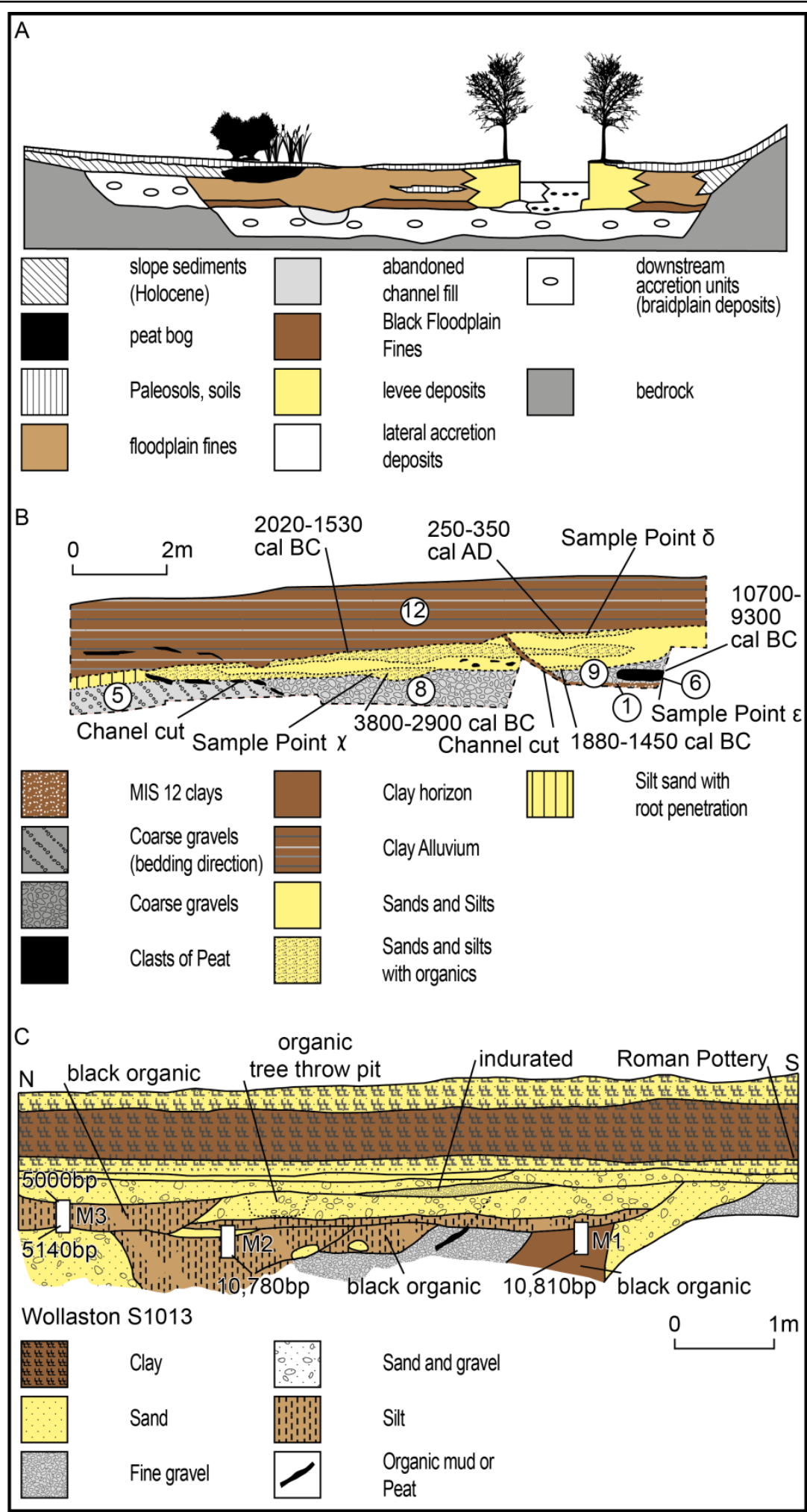

Fig. 4. Three examples of channel-dominated mid-Holocene stratigraphy underlying overbank units. (a) Simplified model of fluvial architecture of a suspended-load river in central Europe, (b) at Croft a small floodplain (100-200 m wide) shows a major Lateglacial palaeochannel subsequently re-cut by smaller midlate Holocene streams which incised and reworked extensive amounts of gravel, coarse sand and organic silts. At some point in the late Iron Age or Roman period (post $800 \mathrm{BCE}$ but before 250-350 CE) approximately $1 \mathrm{~m}$ of clay was deposited across the entire valley floor, confining the channel within cohesive banks from the late Roman period until modern times. The pollen, beetle data and archaeological data (evidence of houses and farming) showing that it was unambiguously associated with human clearance of the deciduous woodland and its replacement by a mixture of rough pasture and arable cultivation. (c) A similar multi-period cross-section from the river Nene (UK) shows an early Holocene basal channel buried by minor channel fills all buried under a cover of silty clay which dates to the Roman Period. 
agricultural land conversion in the British Isles as determined from radiocarbon dates (Stevens and Fuller, 2012). In smaller systems the combination of human impact including milling produced conspicuously different floodplain aggradation rates in neighbouring stream section in the (late) Early Middle Ages (Houben et al., 2013).

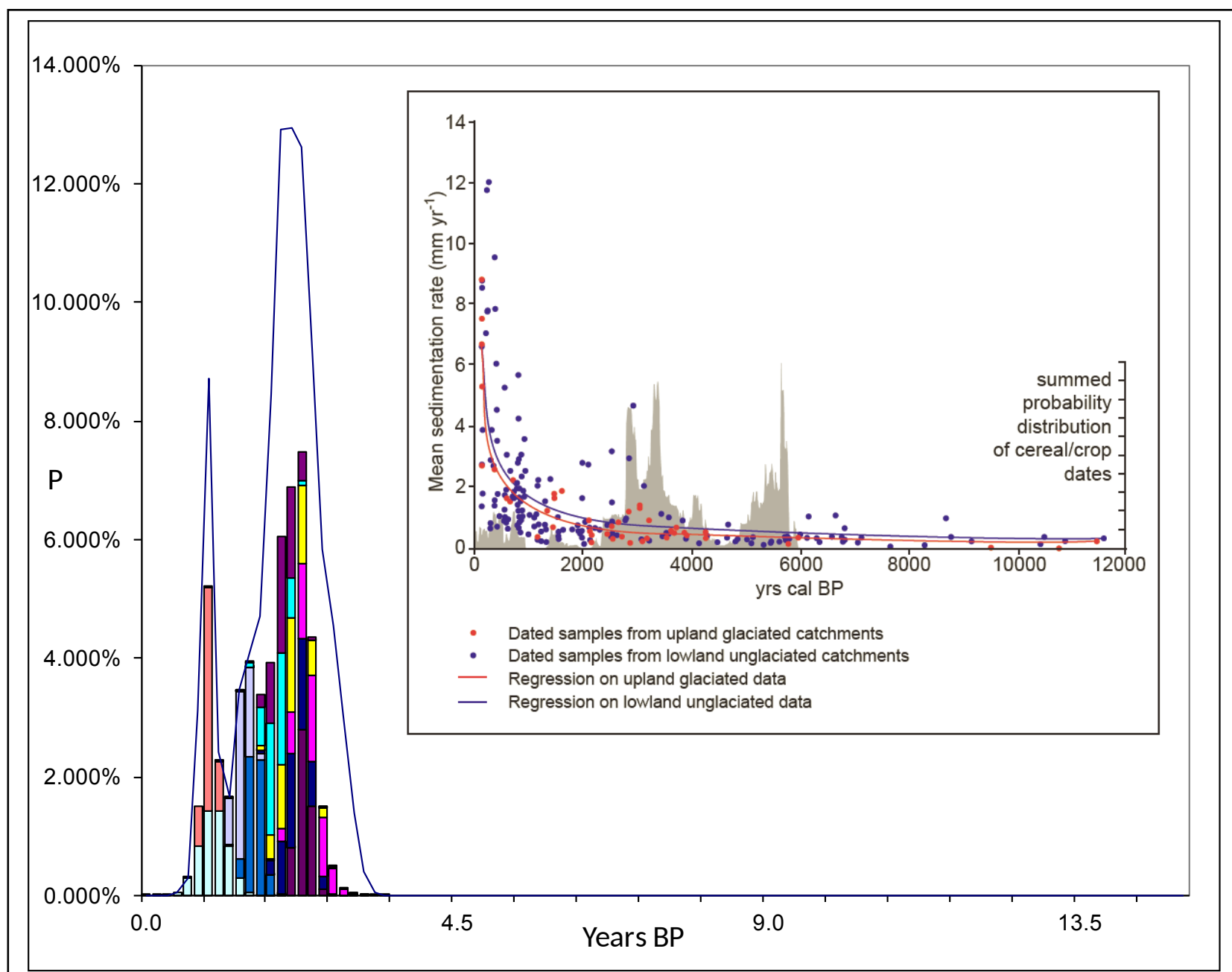

Fig. 5 SPD of 19 OSL dates from the upper alluvial member at 4 sites in the Severn-Wye Basin, UK with inset of SPD of radiocarbon dates of alluviation from Macklin et al. $(2010,2014)$ and cereal/crop dates archaeology from Stevens and Fuller (2012) reproduced in Brown et al. (2016) 


\subsection{Palaeoecological Studies of Floodplain Transformation}

Palaeoecological studies of buried channels and floodplains reveals a high biodiversity in plant macrofossils including species and habitats which are today extremely rare (Wildhagen-Mayer, 1972; Rittweger, 2000). These habitats include wood-choked alluvial woodland rich in invertebrates
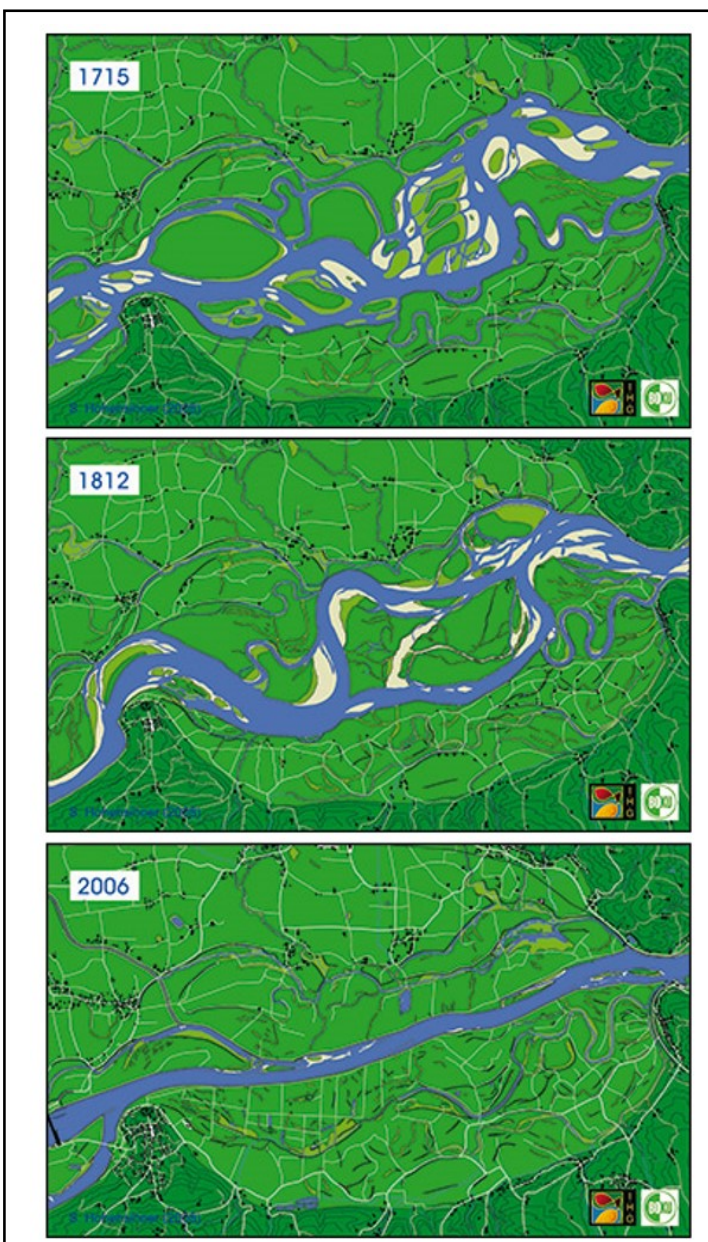

Fig. 6. Channel changes of the Danube River in the Austrian Machland floodplain from 1715 to 2006.Credit: FWF project Machland 17151991. Nr. P14959-B06.
(Harper et al., 1997; Smith, 2000), riparian and floodplain yew (Taxus) woodlands (Branch et al., 2012), species-rich hay meadows (Robinson, 1992) and bracken infested floodplain clearings (Brown, 1999). This high biodiversity was the result of high patchheterogeneity, under intermediate disturbanceregimes as has been shown from the key-stone palaeobeetle faunas (Davis et al., 2007). The contraction from multi-channel forms to single channel patterns is not only common for small streams, but also mediumsized rivers; examples include the middle and lower Thames (Sidell et al., 2000; Booth et al., 2007), the Severn and its tributaries in the UK (Brown et al., 1997), the Seine, Mosel, and Isère in France (Mordant and Mordant, 1992), the Weser, Werra and IIme and many other floodplains in Germany (Hagedorn and Rother, 1992; Girel, 1994; Stobbe, 1996; Zolitschka et al., 2003). It also applies to the basin sections of the largest European rivers such as the Vistula (Starkel et al., 1996; Maruszczek, 1997) and the Danube, with one of the best examples being near Bratislava in the Linz basin (Pišŭt, 2002). An additional factor with these rivers was the improvements required to allow larger draught river traffic after the adoption of steam-boats (Hohensinner et al., 2011 Fig. 6). The reduction of complexity produced by secondary channels, and the prevention of avulsion was the main goal of all the European big river channelization schemes of the late $18^{\text {th }}$ to early $20^{\text {th }}$ century CE channelization schemes (Petts et al., 1989; Gurnell and Petts, 2002).

\section{Channel obstructions and secondary transformation}


Prior to and during the Quaternary, European rivers functioned naturally witha wide range of channel obstructions, most notably those caused by Eurasian beaver (Castor fiber) dams and accumulations of large wood (Coles 2006; Francis et al 2008). Wooded riparian corridors provide a variety of dead and living wood sizes, seeds and propagules directly into the channel network. Living wood and seeds interact with hydro-geomorphic processes to stabilise emergent depositional features and river banks, forcing channel stabilisation (Tal., et al., 2004) and island formation (Gurnell and Petts 2002). Francis et al. (2008) argue that prior to deforestation many natural alluvial lowland channels would have been island braided with a high channel margin length supplying large quantities of woody material into the river network. Conversely, floodplain deforestation which occurred in broadly two phases (2500-2000 BP and 1500-1000 BP) reduced the supply of wood, seeds and propagules, which would have resulted in increased channel dynamics in reaches of high stream power due to absence of stabilising root systems on river banks, and vegetation of bars and islands. In zones of low stream power these effected were probably cancelled out by the increasing rate of overbank siltation by cohesive sands, silts and clays (Brown et al., 2013).

In headwater streams the role of wood varies since the processes of supply are influenced by slope processes (shallow landslides) and channel width:wood ratios (Dixon and Sear, 2014). Large wood recruitment in headwaters can block valleys forcing aggradation of the valley floor (Montgomery and Abbe 2006). Similarly, low width:wood ratios promote the formation of logjams, that force floodplain dissection by overflow channels, and increased water levels upstream of jams. Rates of sediment and organic matter transport from headwaters are strongly influenced by logjam dynamics (Assini and Petiti, 1995; Sear et al., 2010). However, by c. 2,200 BP (the late European Iron Age) human-induced alluviation had changed floodplain and channel morphology and ecology throughout temperate Europe, and floodplains were extensively used for agriculture (Brown, 1997a; Stobbe, 1996, 2012). By the c. 1700 BP (the late Roman period) most natural floodplain wetlands had been drained, and if not then by c. 1200 BP (the early Medieval period). A second transformation was the creation of floodplain-based power supply systems by the 900-600 BP (the $11^{\text {th }}-14^{\text {th }}$ centuries CE or 'High' Medieval period), which were constructed, controlled and maintained by specialised professionals (surveyors or leviadors) for milling and hydraulic engineering (Rouillard, 1996). Under the European Feudal system floodplains and channel were immensely important and regulated. This included regulations for bank protection, channel 
maintenance, fisheries, sewage discharge, floodplain mowing and controlled flooding known as warping in parts of England (Lewin, 2013).

The result was that weirs, watermills, causeways and bridges and other channel obstructions became a ubiquitous feature of all small European rivers as floodplains became the centre of this Medieval technological revolution (Reynolds, 1987; Munro, 2002; Lewin, 2010). This is part of what Lewin has termed the morphological phase of floodplain transformation or genetic modification (Lewin, 2013). At the hub of this development was the watermill which although in existence in Roman Europe, was relatively rare until the early Medieval period, for reasons that appear to be essentially cultural-political rather than technological (Bloch, 1935). For example, by 830 CE the monks of St-Germain-des-Prés (France) had established as many mills as possible for the available hydraulic head as illustrated by the existence of the same number on the same sites in the late 18th century CE (Lohrmann, 1989). The construction of mills also extended from west to east into the formerly non-Romanised parts of Germany in the 7th to 12th centuries CE. Although there is no single data source across Europe, or even at the State level, where historical records do exist, such as for tributaries of the middle Thames Valley, they reveal a remarkably high frequency of river

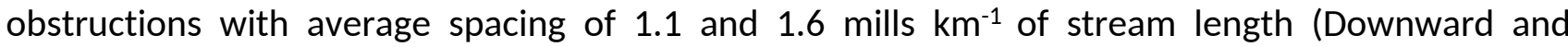
Skinner, 2005). By the the $11^{\text {th }}$ century CE as revealed by the Domesday Book (1086 CE), there were at least 5624 watermills in England (Open Domesday Project, 2017). Calculations for the upper Thames suggest a density of 0.2 mills km$~^{-2}$ (Peberdy, 1996) and estimates based upon historic maps and archaeology suggest higher spacing on smaller rivers such as 2.9 mills $\mathrm{km}^{-1}$ on the Erft River (Germany), 1 mill km$^{-1}$ and around 0.7 mills km-1 for the rivers of orders 2 to 5 in Normandy (Lespez et al., 2005, 2015; Beauchamp et al., 2017). The high density of mills is surprising given the very low gradients of these rivers $\left(10^{-3-}-10^{-4} \mathrm{~m} \mathrm{~m}^{-1}\right)$ limiting the longitudinal gain of hydraulic head (Downward and Skinner 2005; Mordant and Mordant 1992). By the 11th-12th century CE the typical size of an overshot water wheel in England was $1.4-2.5 \mathrm{~m}$ in diameter and this would constrain spacing to approximately one mill every $10-20 \mathrm{~km}$ in small catchments $\left(<10 \mathrm{~m}^{-3} \mathrm{~s}^{-1} \mathrm{maf}\right)$ or less for undershot wheels. However, in Normandy long mill leets ( 0.5 to $1 \mathrm{~km}$ ) could generate 1.5 to $3 \mathrm{~m}$ of head. Examination of the location of mills in many small valleys reveals that they are typically located at the edge of the floodplain and in an alternate spacing downstream. It has generally been assumed that the multiple channel pattern associated with watermills (leets, bypass channels and tail-races) are artificial and were dug when the mill was constructed (Vince, 1984; 
Downward and Skinner, 2005). However, observations on the River Culm and River Erft suggests that many mills utilised pre-existing secondary channels at floodplain edges and exploited a lateral gradient between channels, rather than longitudinal gradient (Felix-Henningsen, 1984; Kreiner, 1996). In Normandy this was often a transitional state (with two remaining channels) in between the marshy floodplain with anabranching channels and the 'artificial streams' of the Middle Ages. The bi or tri-channel form also allowed minimal work to be entailed in the construction of tail-races and bypass channels and restricted conflict with other river users such as for fishing. Support for this hypothesis comes from recent studies of early watermills in England (Lewin, 2010; Downward and Skinner, 2005), administrative boundaries and place name evidence (see Section 5). In Flanders the cellerar was responsible for the maintenance the network of interconnected channels/canals (Rouillard, 1996; Lespez et al., 2005).

During the Mediaeval period the other main engineers of European waterways and wetlands - the Eurasian beaver - was hunted to near extinction (Wells et al, 2000). Territories were reduced to a fraction of their maximum extent earlier in the Quaternary (Coles, 2006) and in many countries populations were eradicated by the 16th century CE with isolated survival in a few protected forests in the peripheries of Europe such as parts of Scandinavia, Eastern Poland and Russia (Halley and Rosell, 2003). Such an impact, in parallel with the human-induced channel changes described above, likely contributed to the within-bank, single-channel structures that prevail in most European rivers to date Whilst it is extremely difficult to measure its past effect the beaver is known, largelyu from studies in North America, to promote channel bifurcation through lodge and run creation, increase pools and increase habitat complexity and diversity including fish (Häglund, 1999; Law et al., 2016). Its reintroduction to many European rivers is being monitored at a number of locations (see Section 9). In addition to the loss of beaver large wood in the form of channel spanning logjams, isolated pieces (snags), bank and island jams were formerly more prevalent in watercourses, but were removed during the Medieval period as rivers were developed for navigation as well as milling, and as riparian forests were cleared.

From the Medieval period onwards, man-made obstructions, mostly weirs, became a the dominant artificial structural component of European rivers as can be gauged from data for England and Wales (Fig. 7). Weirs were built principally to provide the hydraulic head for mills, but also for fishing and the maintenance of adequate channel depth for navigation (Bennett et al., 2014; Lobb, 
2017; Lobb et al., subm.). Obstructions to European rivers have always been controversial as they raise conflicting financial interests particularly between fishing and navigation. Indeed in clause 33 of Magna Carta (1215 CE) the English barons demand of King John the removal of "Omnes kydelli de cetero deponantur penitus de Thamisia, et de Medewaye, et per totam Angliam, nisi per costeram maris" translated as "All fish-weirs are in future to be entirely removed from the Thames and the Medway, and throughout the whole of England, except on the seacoast" (The Magna Carta Project, 2017). Although these weirs obstructed the main channel, they typically did not obstruct the floodplain over which non-riparian rights applied. So only in rare cases in the post-Medieval period were cross-valley dams built which have created stepped floodplain long-profiles (Fig. 8A) as reported for the Mid Atlantic USA (Walter and
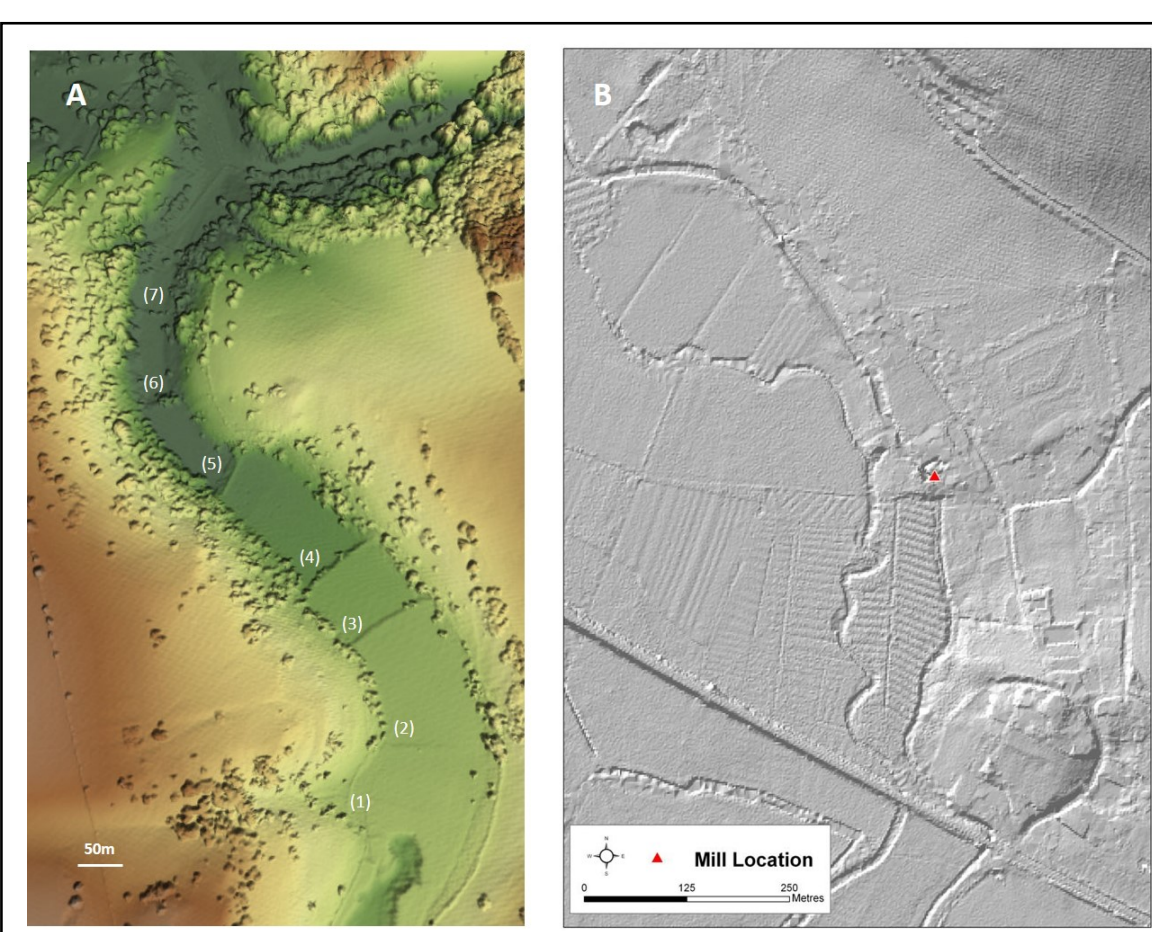

Fig 8. Contrasting floodplain microtopgraphy: (A) LIDAR data from the Velvet Bottom catchment in the Mendip Hills, UK. The area of erosion back into the floodplain surface is marked below the lowest dam (1) of the 7 dams marked. Data by courtesy of the Mendip Hills AONB and (B) Lidar from the River Avon, Hampshire (UK) showing the location of the mill, the patchy nature of the floodplain surface and downstream herring-bone pattern water-meadows.

Merritts, 2008) where similar long-standing legal considerations did not apply. In Europe dams across entire floodplains can be related to metal mining and in Western France, dams across the entire floodplain called "chaussée" were on 4th to 6th order rivers on the south Armorican massif (Lespez et in press). However, in general that stepped longitudinal floodplain gradients can rarely be detected although the mill is part of a complex channel and floodplain mosaic which 
includes water meadows in the UK and France from the $17^{\text {th }}$ century CE onwards (Cook and Williamson, 2007; Fig. 8B). The final transformation of floodplains was universal channelisation and stabilisation with hard-engineering in the industrial period with virtually all small streams being converted into ditches or channelized (Brookes 1988).

Another impact on wooded, sloping low-mountain areas particularly in Germany and Scandinavia was the modification of rivers into 'floatways' for and by timber floating after logging (Tornlund and Ostlund, 2002; Nillsson et al., 2005; Helfield et al., 2012; Comiti, 2012). This may have started in Roman times, was common during the Medieval Period and really increased in Eastern Europe and Scandinavia as the timber frontier migrated inland in the late $19^{\text {th }}$ and early $20^{\text {th }}$ Centuries CE (Törnlund and Östlund, 2002). In these rivers it involved the removal of natural obstructions sometimes by blasting, the construction of splash dams and the confinement of the river into a single channel (Törnlund and Östlund, 2002; Steinle and Herbener, 2016). There have been few studies of its effects but results from one restoration scheme on the Pite River in Sweden showed little re-establishment of a flood-adapted plant communities, although this was only after a period of 5 years (Helford et al., 2012).

\section{River names, place names and river corridor character}

River names and water-related place names constitute a valuable, and underused, data source on the character of historic riverine landscapes in Europe and parts of the New World where aboriginal languages have been recorded. River names are probably amongst, if not the, oldest words in most languages, and many have toponymic meaning relating to landscape form, water quality, vegetation or notable animals (Strandberg, 2015). Although difficult to date precisely in Europe they date from at least c. 1000 BP and may well be older (Coles, 1994: Peust, 2015). In some cases they can even be traced across Europe, even when their meaning is unclear, and it has been argued that some may pre-date Indo-European languages (Coles, 1994; Peust, 2015). Water-related names allow several distinctive characterisations to be made, adding a further layer of landscape evidence to the physical, biological and archaeological datasets that already exist, and providing an alternative basis by which these can be tested and evaluated. Initially water-related names allow researchers to describe physical features and landscapes as shown by the common and shared etymology of river names across Europe (see Table S1). Another distinctive advantage of waternames is that they can be utilised at a number of different scales: since names are thought to have 
Many river names contain remarkable detail about their hydrological character (Ekwall, 1928). When viewed together, British river names seem to indicate five different river-types, defined by Jones (pers. comm.) as: 'idlers' characterised by a slow water flow and low flood risk (e.g. Rivers Seph and Brit); 'lingerers', whose floodplains are typified by areas of consistently wet ground (e.g. Rivers Leach and Sowe); 'meanderers' whose highly sinuous watercourses and wide floodplains present a higher risk from flooding (Rivers Camel and Wensum); 'wanderers', rivers which tend to demonstrate marked lateral channel movement and propensity of overbank (Rivers Irwell and Trent, Jones et al. 2017); and 'aggressors', characterised by fast flowing water and prone to flash flooding (Rivers Erewash and Swale). This previously untapped data source is being used in a current project in the UK called Flood and Flow: Place-Names and the Changing Hydrology of RiverSystems (Flood and Flow, 2017). The nature and character of rivers in mainland Europe have also been encapsulated within the origins of their names. Examples of rivers with rapid water movement can be seen in the French rivers Rhine and Isère interpreted from the Indo-European rei and -isərós respectively and have been interpreted as 'to move, flow or run' and 'impetuous, quick, vigorous' (OED 2001, Delamarre 2003, Roussel 2009). Additionally, the river Aude takes its name from the Gaullish -atacos meaning 'spirited or very fast' and the Liffey in Ireland from the Irish Gaelic -An Ruirthech 'fast, stong runner'. In Germany examples of rapid water movement is

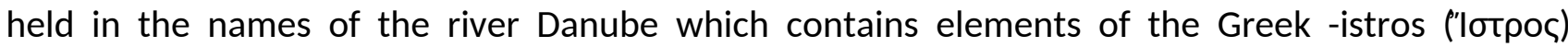
'strong, swift' (Katičić 1976) and the Aar with the early German for quick flowing water (Krahe 1964). Further east in Poland the river Poprad contains components deriving from Proto-Slavic and Slavic -pręd-and -priast' meaning 'to flow fast, to jump or spin' (Ondruš 1991). In contrast there are also examples of hydronyms which illustrate the slow movement of water. In Poland the interpretation of the river Vistula is from the Indo-European -ueis meaning 'to ooze or flow slowly' (Adams 1997). Slower moving water may also be inferred from river names which refer to the 
colour or sediment held within them. In France the rivers Loire, Loir, Loiret and Ligoure all contain the element -liger the latinised version of the Gaulish -liga which refers directly to silt, mud and alluvium (Montclos 1997). Other examples include the Brian, Briance, Brienon and Briou from the French -boue or 'mud' (Toponymie Rivieres de France 2002). Gentle riverine conditions may also be interpreted from water names suggesting a sinuous, meandering course. Examples include the River Kocher in Germany which derives from the Celtic -cochan 'winding or meandering' (Lott 2002), the Schunter from Slavic -sukqtora 'with many angles' or Loobah from Gaelic Irish -An Lúbach 'twisted one'. In Norther Europe in Sweden and Norway the addition of -sele to watercourses indicates low gradient rivers associated with former glacial lakes and deltas.

In relation to water-related place names the composite nature of the English language, influenced over time by many languages such as; obscure ancient languages (Brittonic - the Celtic languages spoken in Britain); Latin; Old English; Old Norse and French, means that place names contain a greater diversity of terms describing watercourses and floodplain topography than exists today. For the UK, key texts such as Gelling (1984) and Gelling and Cole (2000) provide detailed analysis of the vocabulary used in these names and the fluvial features or phenomena which they describe. However, the investigation of these names allied to geomorphology remains rather undeveloped with notable exceptions including research in the River Trent (Brown et al., 2001; Jones et al., 2017) and on-going work in the Severn-Wye catchment (Flood and Flow, 2017). The importance of water in the early medieval period in England appears to be reflected in the sheer number of place names that refer both directly and indirectly to it. It is believed that these were conscientiously and carefully chosen in order to highlight the presence, nature and behaviour of water, and inform occupants and travellers of local conditions. A particularly good, yet rare example of this can be found in the place names Buildwas (River Severn), Broadwas (River Teme), Alrewas (River Trent), Hopwas (River Tame) and Wasperton (River Avon). The -wæsse (..was) element derives from the Old English and has been recently reinterpreted to indicate an area which floods and drains rapidly (Gelling and Cole 2000).

Evidence of flora and fauna within river and place names can also assist the understanding nature of the past river corridor ecology and landscape. For example the inclusion of beaver-derived names across Europe is common-place and include the rivers Bèbre, Beuvron, Bibiche, Bièvre and Bièvre in France derived from the French -bebros (Toponymie Rivieres de France 2002). There are 
also many names derived from floodplain vegetation such as forested rivers, an example being Aberdare and Aberdaron which both come from 'mouth of the oak river' (Welsh Celtic, Mills, 2011). The name Gearagh (see Section 6.1) or 'Gaertha' is a word peculiar to Co Cork and Co Kerry in SW Ireland that means 'level wooded tract near a stream or river' as noted in 1840 CE, by John O'Donovan in the Ordnance Survey Name Book where it appears as Gaorthadh an Róistigh/Gearagh (Míchaél Ó Mainnín pers comm., 2018; Logainm.ie, 2018). Water-related names can also illustrate distinct links with past human land use. Studies in France and specifically Normandy have suggested that the hydronomy (names for bodies of water) provides indications on the past river pattern prior to the start of the Middle Ages and development of numerous water mill systems. For example, variants of Old Norse in water-names including -bec 'a small stream' and -dik or -dic(q) 'a waterfilled ditch' indicate the management of running water. Such toponomy underline the significance of the artificialisation of the river system since the Middle Ages (Cador and Lespez, 2012). In this area, more than 700 leets still remain for a length of $540 \mathrm{~km}$ and numerous rivers have changed their name to the name of the leet. Thus, from the 19th century at least, the Mue River named the former leet while the Douet (local name for the leet) named the small stream remaining in the natural thalweg! More generally, the detailed examination of the maps of Western Normandy reveals more than 60 "Douet" and 40 "watermill brook" (ruisseau du moulin) and also a number of "dead" rivers (Morte Eau, La Morte, Morte-Vie) and some "fake" rivers (fausse rivière) indicate abandoned rivers because of the diversion of the flows to the leet. Moreover, in the Calvados district, there remain 280 watermills in the toponymic inventory of the local map of Institut Géographique National illustrating the imprint of the long-term transformation of French and European streams. Whilst this brief introduction to the topic has only been able to highlight a few river and place name examples from the British Isles, and mainland Europe it suggests that combined palaeoenvironmental and etymological investigation in the future could both open a window on river conditions in Medieval Europe, but also provide rare data on past societal perception of rivers and their landscapes.

\section{Case Studies: hydroecological processes and biodiversity in forested European floodplains.}

\subsection{The River Lee, SW Ireland}

Alluvial forests are a rare habitat in both the UK and Europe but have disproportionately high biodiversity (Brown et al., 1997). Studies on the Gearagh alluvial forest on the River Lee in Ireland, have revealed the coexistence of a multitude of small islets of uneven height separating channels 
which have different substrates, slopes, roughness and residence times (Harwood and Brown,

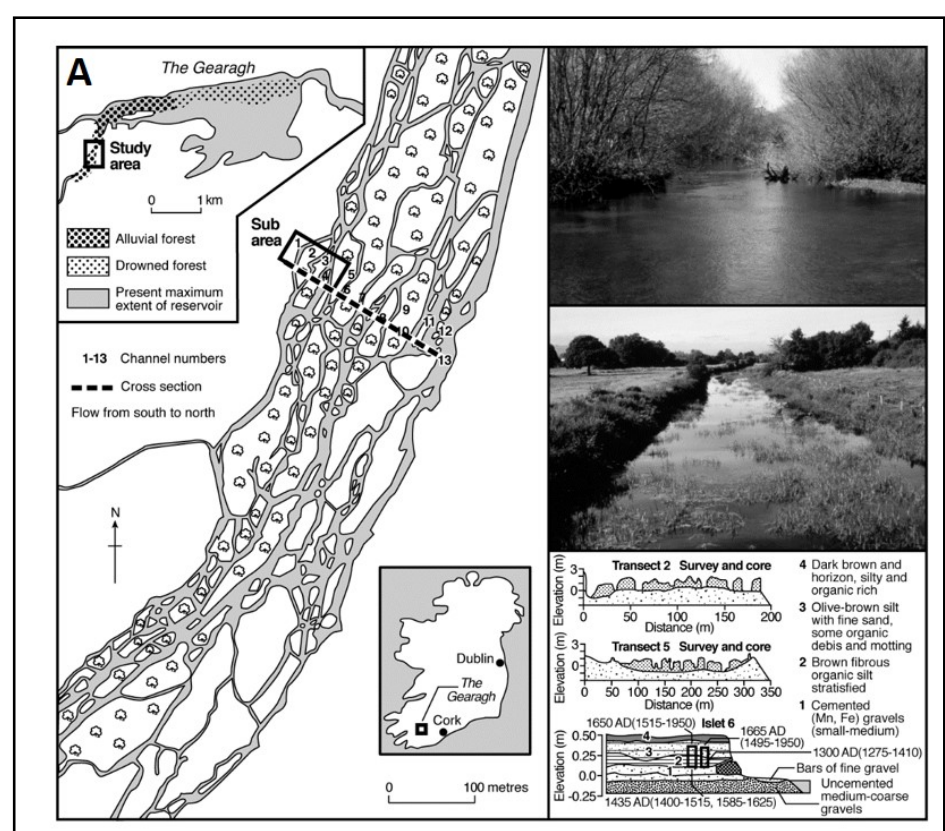

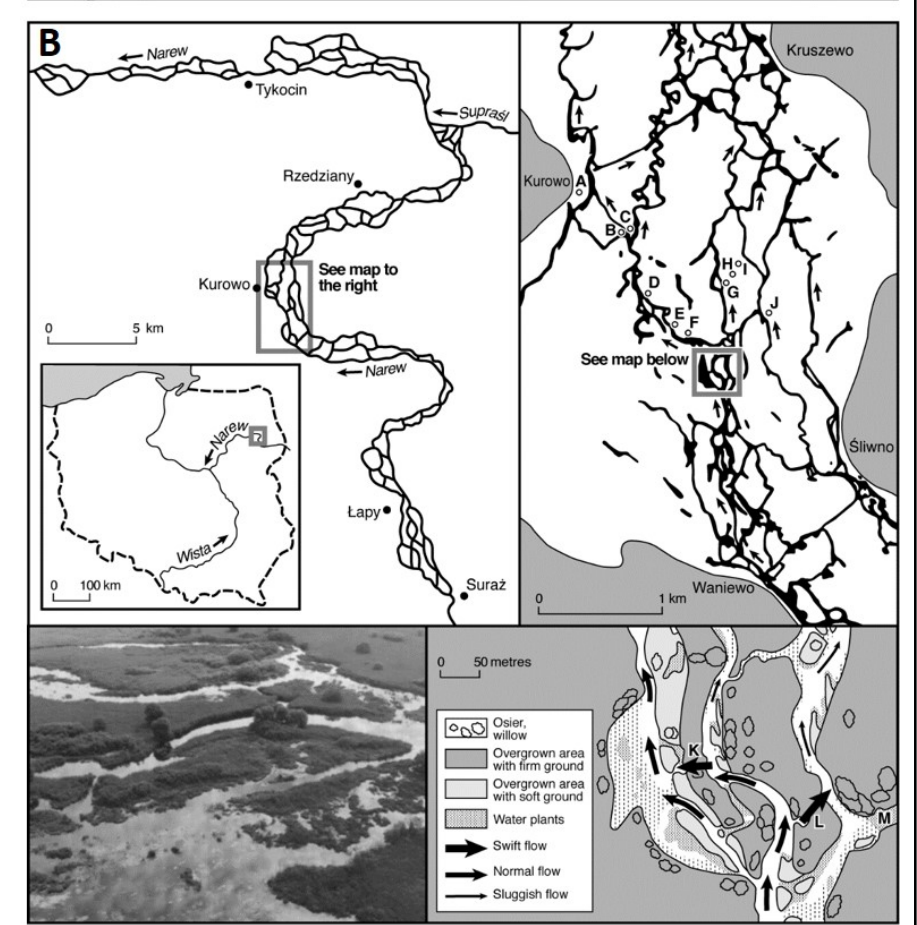

Fig. 9. Two examples of rare surviving anastomosing channels in Europe; (A) the anabranching river system of the Gearagh in SW Ireland, and a tributary of similar size from an alluviated subcatchment which joins the Lee at the Gearagh, (B) the Narew in northeast Poland. 1993; Brown, 1997b, Fig. 9(A)). Treethrows and debris dams are responsible for highly irregular banks, scour holes and the cutting of cross-islet channels which has created this intricate planform (Fig. 8a). Partial organic dams constructed of wood, brash and leaves occur in almost all the secondary channels and is associated with backed up water and pools. The overall result is high biodiversity in a wide range of organism groups from sponges, through beetles to birds (Brown et al., 1995) and of particular significance is the survival of yew (Taxus baccata) in the forest which otherwise has only been noted from mid-Holocene sediments such as in the Lower Thames (Branch et al., 2012). It was initially thought that the system was almost entirely natural but ${ }^{14} \mathrm{C}$ dating of peats at the base of several islands all produced Medieval dates (c.1300-1600 CE, Fig. 8) which strongly suggests a transformation of the system by a confining wall and embankment which cut-off a larger network of palaeochannels which now lie under agricultural land. This structure was probably built during the Medieval period either related to the early Medieval Church at the eastern end of the Geargh (Macloneigh Church) or during the agricultural intensification of the early Norman period when a castle was built at the downstream end in Macroom (Cudmore, 2012). Early maps and drainage records reveal that other rivers in the 
area such as the Brandon and Bride were also of this anastomosing form prior to agricultural improvement and deforestation in the historical period (Cudmore, 2012).

\subsection{The River Narew, Poland}

The North European Plain, which varies from about 150km wide in Belgium to $1200 \mathrm{~km}$ eastwards in Poland, is about $900 \mathrm{~km}$ in width between the Lublin Uplands and the Bothnian Bay. During the Pleistocene the plain was covered several times by the Eurasian-Scandinavian ice-sheets, which left a legacy of recessional glacial deposits. Under favourable conditions of the substrate and topography, extensive areas were covered by dead ice, protected from melting by covering glacifluvial deposits creating distinctive landsform-substrate assemblages. During the last cooling period of the Pleistocene - the Vistulian (Weichselian) - in Poland the ice sheet crossed the depression of the Baltic Sea and reached approximately $200 \mathrm{~km}$ to the south from its present coastline. As recession progressed, the proglacial waters from the SW margin of the ice sheet flowed due west through the ice-marginal streamway system and eventually after approximately 2,000 km flowed into English Channel and the Atlantic. In the NE part of Poland glacifluvial deposits partially covered the other glacigenic deposits of older glaciations (Mojski, 2005). Currently this region is drained by the tributaries of the Vistula river, including the anastomosing Narew river, flowing into the Baltic Sea (Fig. 9B).

The Narew drainage basin mostly covers glacigenic Quaternary deposits, with a thickness of over $100 \mathrm{~m}$. These include not only boulder clays/diamictons/tills but also glacifluvial as well as glaciolimnic deposits, both older and concurrent with the last ice-sheet advance. The source area of the Narew river is located in a marshy and heavily forested part of Western Belarus. Its upper section, with a latitudinal course from $\mathrm{E}$ to $\mathrm{W}$, is about $70 \mathrm{~km}$ long and drains $3,370 \mathrm{~km}^{2}$. In Poland the Narew River valley changes its course to the meridian and through several large bends runs north. For about $40 \mathrm{~km}$ and with a floodplain 1-4 km wide, the Narew river displays a typical anastomosing channel pattern. This section of the valley has a gradient of $0.18 \mathrm{~m} \mathrm{~km}^{-1}$ (Fig. 8B). Within its course are basin-like widenings of the valley, resulting from the melting of extensive icefields covered during the ice-sheet recession by glacifluvial or fluvial deposits (Mojski, 2005) (Fig. 8B). Today the Narew drainage basin lies in the Central Europe in the temperate transition zone. This causes the advection of varied air masses, mainly the western cyclones and eastern anticyclones (Ustrnul and Czekierda, 2009). This result is a strong contrast of summer and winter 
temperatures and varying seasonal precipitation. In the last decades of the last century, $25 \mathrm{~km}$ east of the meteorological station at Białystok (northeastern Poland), absolute maximum air temperature reached $36^{\circ} \mathrm{C}$ (13 July 1959), and absolute minimum $-35.4^{\circ} \mathrm{C}$. Average annual rainfall ranges from $450 \mathrm{~mm}$ to $560 \mathrm{~mm}$, with the lowest rainfall in February, and the highest in July. Snow cover lies usually from mid-November to mid-April, and on average lasts 80 days a year (Ustrnul and Czekierda, 2009). Between 1951-2010 the mean yearly water discharge of the Narew river was $15 \mathrm{~m}^{3} \mathrm{sec}^{-1}$. After prolonged precipitation and especially during snowmelt in spring and the melting of thick ice cover of frozen channels, it reaches up to $150 \mathrm{~m}^{3} \mathrm{sec}^{-1}$. The establishment of the Narew National Park in 1988 stopped work aimed at "regulating" the natural network of channels and prevented their destruction and led to the preservation of woodland and relatively natural vegetation conditions. It also provided basic information about the variability of geometry and the depth of the river channels as well as the vertical sequence of alluvia in this section of the Narew Valley. It was found that the valley cuts mostly into boulder clays deposited by the last transgression of the European-Scandinavian ice sheet and are filled with sedge (Carex) peat. At $3 \mathrm{~m}$ depth sandy alluvia contain sporadic organic remains and radiocarbon dates fall within the range of $3,100 \pm 240$ BP to 3,260 \pm 90 BP BP (Gradziński et al., 2000). These sediments are covered with a layer of peat, with a thickness of $0,8-1,5 \mathrm{~m}$. The rate of vertical accretion is $0.3-1.6 \mathrm{~mm}$ year ${ }^{-1}$ from c. 2,600/2,000 until 1000 years ago (Aleksandrowicz and Żurek, 2005). Climate changes within the last two millennia, and in particular the extreme cooling in the North-Eastern Europe dated at 536 year CE and several extremely cold minima of the LIA had a profound influence on this area causing rivers to completely freeze over for many winters, which in spring periods resulted in the formation of ice-jams. Channels of the Upper Narew retained an anastomosing form (Gradinski et al., 2000), have low gradients, are laterally stable, have relatively low banks and are generally straight with sandy beds and no levees or point bars The low banks of the anastomosing channels of the Narew river were conducive to the creation of new branches of the river through flood, ice-jam, log-jam, beaver and elk path controlled avulsion.

\subsection{The New Forest, England}

The New Forest is a small remnant of ancient forest in southern England that has been managed for at least 1000 years initially as a hunting ground for Royalty, then for naval wood supply and latterly for amenity (Tubbs, 2001). The New Forest is unique in Europe having a written record of management spanning over 1000 years as well as an unusually dense palaeoecological record 
derived from many small valley mires (Grant et al., 2014). These studies have shown that some areas, and particularly Mark Ash Wood, have remained wooded throughout the Holocene having

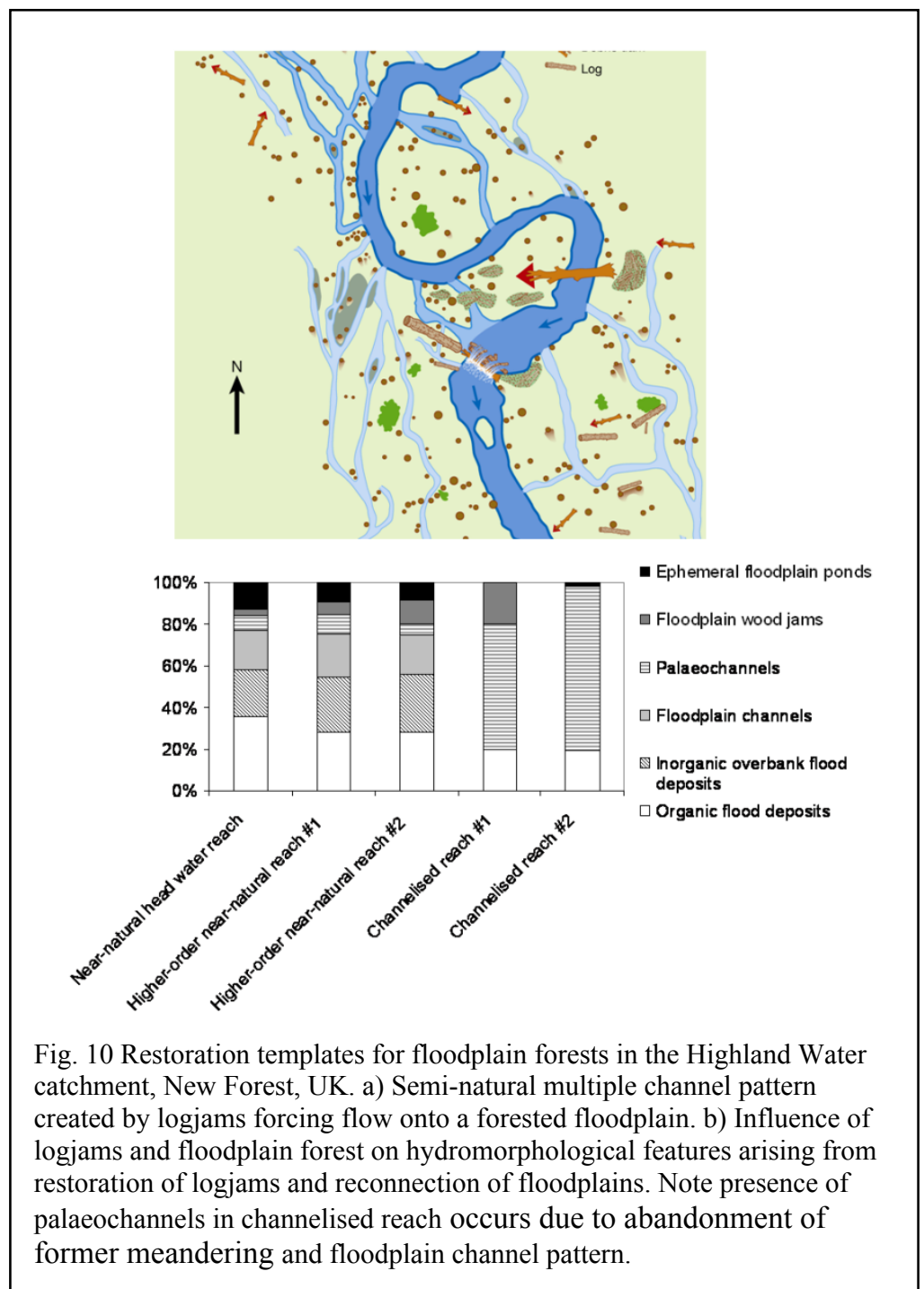

never been cleared for agriculture. Long running studies in the catchment have shown how small but complex channel and floodplain morphologies are controlled by the dynamics of wood (Gregory et al., 1993; Sear et al., 2010). Log jam dynamics control the frequency, location and duration of floodplain connectivity (Fig. 10), generating foci for erosion of the floodplain surface and deposition of sediments and organic matter; the latter at high rates (Jeffries et al., 2003). Cumulatively, the interaction of water, sediment load, wood, logjams and floodplain forest generate complex floodplain microtopography, and a network of ephemeral channels over the floodplain surface with similar form to anastomosed systems (e.g. the Gearagh; Sear et al., 2010). The complexity of the resulting wooded floodplain and channel hydromorphology, increases form roughness, affecting flood hydrology; although the nature of this change depends on the age of the forest and its location within the river network (Dixon et al., 2016). Ecological studies reveal that the presence of trees and shrubs along with wood in channel and on the floodplain results in cooler streams (Broadmeadow et al., 2010) and higher habitat and species diversity relative to channelized and drained reaches of the same river (Beechie et al., 2010). However, due to the high and managed grazing regime related to ancient grazing-rights as well as deer there is a lack of ground-storey flora and fauna as revealed by beetle analysis which showed New Forest environments to be most similar to Medieval managed parklands (Davis et al., 2007). 
a)

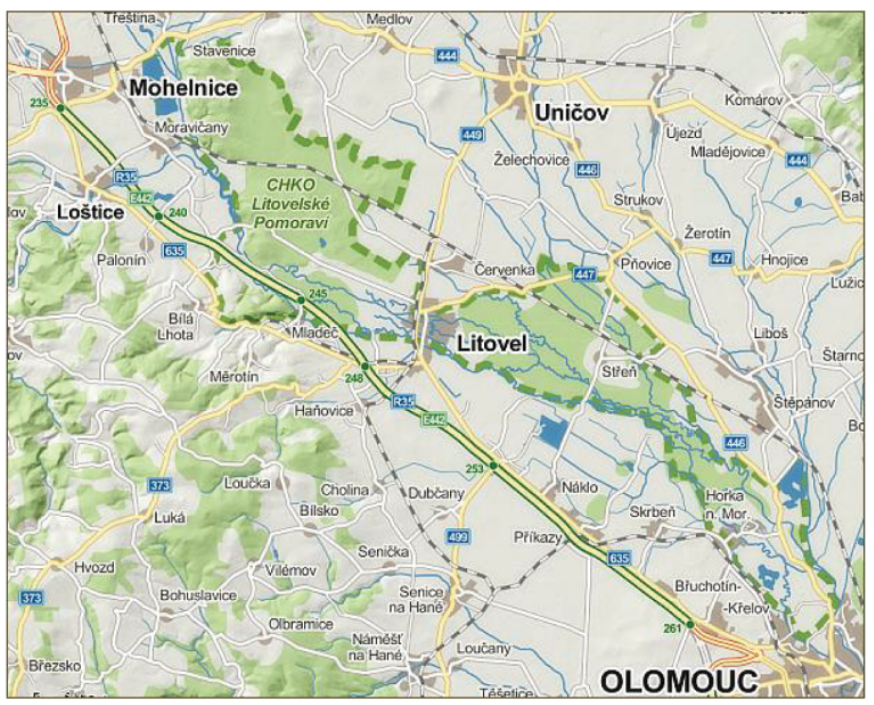

b)

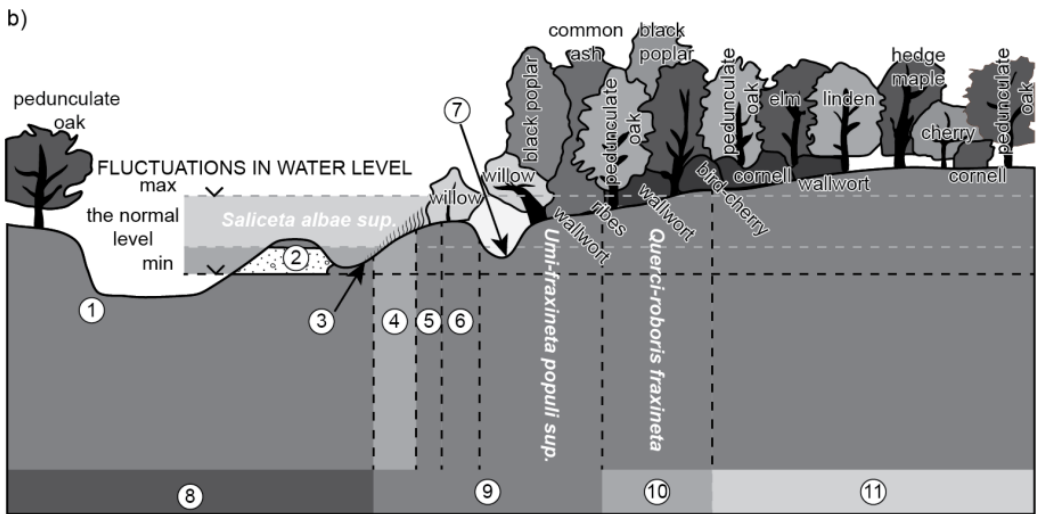

Fig. 11 (a) the location of Litovelské Pomoravi, (b) Fluvial seres of floodplain biotopes in the Litovelské Pomoraví: 1 - stream bank erosion, 2 gravel river island, 3 - sand river drift, 4 - muddy river bank with Bidens sp., 5 - gravel river bank with Phalaris arundinacea, 6 - willow scrub of loamy and sandy river banks, 7 - side arm of river, 8 - main river bed, 9 frequent floods, 10 - occasional floods, 11 - habitats outside area of flooding. From Macher (2008) forest grazing especially of pigs. Within the floodplain forests the river flows in several permanent and ephemeral channels called smokes (hanácky: smohe). These channels gradually dry out during the spring and form pools before becoming completely dry and have a rare crustacean fauna. Although the hydrological (flood) regime is unregulated there are two weirs in the area which maintain water levels and a series of so called "peasant dykes" in canals which distribute water across the forest and have been maintained since the Medieval period. The woodland is elmoak forests with some oakhornbeam and lime-oak. There are also water meadows and a greater variety of aquatic habitats. Investigations have shown that forest growth and structure are 
entirely dependant on the fluvial regime (Machar, 2008a) largely determining ecosystem state including, e.g., the kingfisher population dynamics (Machar, 2008b). Beavers were reintroduced in 1991 (Klostan and Lehký, 1997; František et al., 2010) and studies have shown that they initially occupied the most favourable habitats, dominated by Salix but later spread out into sub-optimal habitat as they approach a maximum density (John, 2010). They have also helped maintain the complexity of the system and increased ecological complexity outside the Litovelské Pomoravi, along the Moravia river (see later section on beaver effects). Using both historical information and a growth simulation model Simon et al. (2014) have shown that despite its cultural origins the present woodland is sustainable into the near to medium term future in its current state.

All four case studies show multi-channel, anastomosing, and largely wooded systems which are unusual in that they have persisted whilst the vast majority of similar systems have been converted to single channel sinuous or straight channel systems. The reasons for the preservation of these 'exceptions' are unique and historical with two cases being related to the hunting needs of the elite (new Forest and Litovelské Pomoravi) and the other two due a combination of geological history and remoteness. These areas remain some of our few remaining models of pre-transformation alluvial systems in Europe, but all are clearly cultural as much as natural landscapes.

\section{Floodplains as carbon sources or sinks?}

Floodplains can deliver multiple ecosystem services several of which, such as flood-water storage, sediment trapping and pastoral agriculture all have a role in combined carbon storage and potential release (Hughes, 2003; Posthumus et al., 2010; Suftin et al., 2016; Schindler et al., 2016; Wohl et al., 2017). Organic carbon (OC) accumulating in the floodplain generally has two sources, from soil erosion and upstream-and from in-situ biomass. River-borne OC can have three environmental fates. Under anaerobic conditions in stream bed and near-channel sediment microbial activity eventually releases $\mathrm{CO}_{2}$ into the atmosphere (Wohl et al., 2017). Next, carbon is transferred to the ocean bound to particulate matter or in dissolved forms. Finally, carbon can be sunk in floodplains resulting in a long-term fixation of within alluvial floodplain areas. Consequently, the preservation of organic matter reflects long-term carbon sequestration on floodplains and within channel storage (Macaire et al., 2005; Van Oost et al., 2012). A typical feature of pre-deforested floodplains is the localized accumulation of peaty sediments and peats in the form of rheotrophic-eutrophic fens. These peats are part of the sink term prior to disturbance, that should be considered when 
assessing anthropogenic floodplain C, although they are often neglected (eg. Stallard, 1998). These have about $40-80 \%$ organic matter (OM) whereas overbank silt clay deposits may have $2-4 \%$ OM on average. Floodplain sediment profiles do not show systematic changes of past decomposition with profile depth. Nevertheless, organic-rich sediments typically have a high sensitivity to compaction and humification and so mass accumulation rates have to be adjusted for these effects (Ramada, 2003). Calculations from the River Frome suggest that OC storage in the upper inorganic unit amounts to $348 \mathrm{~m}^{3} \mathrm{ha}^{-1}$ (i.e. post-2700 BCE) whereas the underlying organic rich unit contains about $3500 \mathrm{~m}^{3} \mathrm{ha}^{-1}$ and although its date of initiation is not known it is unlikely to have been deposited over more than 4,000 years. A similar case has been shown for pre-European settlement North American floodplains on conversion from marshy swales to mill-dams (Walter and Merritts, 2008; Ricker et al, 2013)

The simplest approximation to the long-term net sequestration of carbon into the floodplain is based upon the $\mathrm{OC}$ of sediments and the flux rate under steady state conditions. The greater rate of accumulation of post-deforestation sediments may partially offset the lower carbon sequestration of agricultural land but this will depend upon the system and may not be the case for peat-forming floodplains typical of groundwater-dominated systems. An approximation for a pre-deforestation floodplain is a mosaic of wet woodland and open reed/sedge dominated fen (nutrients moderate to high). Alder leaves can contribute 5-10 $\mathrm{t}$ ha $\mathrm{yr}^{-1}$ and sedge fen and reed beds up to $20 \mathrm{t}$ ha $\mathrm{yr}^{-1}$ (Lüscher et al., 2004). This, however, is offset by carbon loss as methane $\left(\mathrm{CH}_{4}\right)$ and $\mathrm{CO}_{2}$ outgassing associated with microbial metabolism in biofilms and aggregates. However, this depends upon the degree of connectivity with the main channel and morphology (Ballon et al., 2008; Foster et al., 2012). Overall Ricker et al. (2014) have shown that riparian forest can sequester twice as much as upland plots due primarily to lower microbial respiration and $\mathrm{CO}_{2}$ efflux.

The nearest approximation of post-deforestation semi-improved and improved floodplains is improved grasslands. The carbon uptake of grasslands is dependent upon nitrogen availability typically varying between 2 and 6 tons of carbon ha-1 $\mathrm{yr}^{-1}$ (Suftin et al., 2016; Lüscher et al., 2004). These figures are significantly higher than the $C$ storage measured for the present Rhine floodplain of 0.05-0.17 t ha yr-1 (Hoffmann and Glatzel, 2007) although grassland C uptake is only representative for a short period of time (decadal timescales), so it is hard to compare it with millennial scale $C$ storage as these systems will reach a steady state with respect to $C$ rather quickly. 
However, using these figures it is suggested that during the alluvial transition the carbon uptake of floodplains declined possibly by as much as two thirds. This estimate assumes carbon saturation does not limit uptake and does not include the export of carbon from floodplain grasslands through grazing cattle, which would decrease this differential. The within channel $C$ storage, high for forested streams also decreased with deforestation to the low in-stream biomass typical of regulated and channelised reaches in Europe today (Brookes, 1988; RRC, 2002). However, anaerobic conditions common on floodplains are also conducive to the production of methane $\left(\mathrm{CH}_{4}\right)$ and nitrous oxide $\left(\mathrm{N}_{2} \mathrm{O}\right)$. In periodically inundated systems, such as those on floodplains, methane emissions can be highly variable at the timescale of restoration projects. In a study of the carbon implications of floodplain restoration on a section of the river Danube Welti et al. (2012) showed that the hydrology and particularly length of water interchange period, regulated potential denitrification rates but that more efficient $\mathrm{N}$ and $\mathrm{C}$ cycling could produce an overall reduction in potential $\mathrm{N}_{2} \mathrm{O}$ emissions. A potential additional factor which may ultimately resolve the short vs long term dynamics question, is the discovery that anaerobic microbial decomposition is not just energy and mineral limited (reduction of $\mathrm{N}$ and $\mathrm{S}$ ) but thermodynamically limited by microbes 'ignoring' carbon compounds that do not provide enough energy to be worthwhile to degrade and so end up accumulating (Boye et al., 2017). From these results it would appear that in their entirety and in the short-term floodplains may be either sources or sinks of carbon, depending on a their hydrological regime, and can switch between being sinks of carbon to becoming net sources at a variety of temporal scales. This switching can be a natural process due to seasonal or other factors or can be affected by human management as concluded by Wohl et al. (2017). Another important implication is that more research is needed here on both the longer-term balance of carbon storage in, and release from, restored, rewet, or rewilded floodplains applying differing river, groundwater, and floodplain management scenarios. Overall when combined with the appropriate management of the riparian zone river corridor restoration can convert river corridors from $O C$ sources to $O C$ sinks (Wohl et al., 2017).

\section{A biomolecular approach to floodplain ecology}

The storage of carbon in floodplain sediments takes many forms and includes long-chain carbon based molecules many of which are being used as biomarkers of human activity and environmental change. A variety of biomarkers have been obtained from lake and pond sediments including stanols, pyrolytic polycyclic aromatic hydrocarbons (PAHs), n-alkanes, leaf-waxes and biogenic 
silica. Faecal $5 \beta$-stanols, are exclusively linked to human and ruminant faeces and have been used to detect the presence of humans and domesticated animals, and the ratio of different stanol compounds can be used to discriminate and quantify the contribution from each source (Bull et al., 2002; 1996; D'Anjou et al., 2013). Pyrolytic PAHs are produced directly from incomplete combustion of organic fuels (e.g., wood) and in regions where natural forest fires are rare, these compounds indicate the timing and extent of agricultural land clearance and hearth use. Sediment n-alkanes are widespread biomarkers that have been used as indicators of source organisms (e.g. Ficken et al., 2003; Meyers, 2003) the principal sources being algae, bacteria and vascular plants that live within standing freshwater bodies, and from catchment vegetation. Changes in their ratios can reflect transitions between forest and grassland-dominated ecosystems. These techniques are proving valuable in shallow lake and fen-mire systems around wetland archaeological sites (Brown et al. in prep.) and can be applied to floodplains which have not undergone groundwater lowering and water-table fluctuations. Lipids can also survive in organic floodplain soils (Langer et al., 2009) and even from early Pleistocene sediments (Magill et al., 2016).

The revolution in genetic technology and the discovery of the survival of extracellular residual DNA (ancient or aDNA) in sediments also referred to as sedaDNA (Taberlet et al., 2007) has opened up the way for an aDNA-based palaeoecological approach to lakes (Alsos et al., 2015; Alsos subm.), wetlands and possibly floodplains. In fact small floodplain lakes may have high potential as it appears that sedaDNA is preferentially transported bound to clay (Vettori et al., 1996; Cai et al., 2006; Yanson and Steck, 2009). First used in studies of palaeo-biodiversity (Herbert et al. 2003), this approach has been shown to track the variation in the abundance of plants and domestic animals over the last six millennia, enabling the reconstruction of human impacts on alpine lakes through time (Giguet-Covex et al., 2014). The peats contained within many floodplain fills are also potential carriers for sedaDNA (Rawlence et al., 2014; Parducci et al., 2015). At present there are few studies but an ongoing research in Arctic Norway has recovered the sedaDNA of over species from small valley-floor ponds in the Veranger peninsula (Clarke et al. in prep.). The advantage for studies of past floodplain biodiversity are clear in that using different primers, shotgun sequencing or possibly DNA capture techniques, a far more complete assessment of past ecology including mammals, fish, insects and microrganisms may soon be possible and make the exploration of past conditions comparable in depth to eDNA monitoring of contemporary aquatic systems. 


\section{Rewilding versus restoration}

Rewilding takes the restoration of ecological function of rivers and floodplains further than rehabilitation and restoration through the re-introduction (either passively or actively) of locally extinct (extirp) species, generally at the State or regional level (Schepers and Jepson, 2016). The potential therefore varies inversely with the local and regional degree of impact, but there are a number of obvious candidate keystone species for river corridors in Europe. This includes a variety of birds, grazing herbivores (including beavers) and a few other mammals including otters. There are several wetland birds that are now extinct from large areas of Europe and which are associated with floodplains, and a number have been re-introduced or managed for. In the UK the Eurasian bittern (Botaurus stellaris) was very rare with a population falling to 11 birds in the 1990s and entirely confined to marshes in East Anglia, but is now up to 162 males (Hayhow et al., 2017; RSPB pers com. 2017). Numbers have been increased by raising water levels in reed beds in Lakenheath in Suffolk and re-flooding a large area called the Avalon Marshes in the Brue Valley, Somerset (HillCottingham, 2006). There are many other birds that can benefit from rewilding of floodplains, including; waterfowl and waders, river corridor birds and birds of prey, and in several European countries this may be the key objective in restoration or rewilding schemes. In continental Europe the reintroduction of large herbivores has taken higher priority including the reintroduction of an old breed of horse (konik), a rewilded cross-breed of cattle into the Dviete valley marshes in Latvia (van Winden et al., 2011) and the reintroduction of Heck cattle (an analogue for the Aurochs) to Flevoland in the Netherlands (Heck 1951). The design outcome of these and similar schemes is to increase the heterogeneity of floodplains following the work of Vera (2000) who has argued that large herbivores maintained open canopy conditions in primeval European forests. The presence of Pleistocene mammal bones from large fauna, including Straight-tusked Elephant, Hippopotamus and Giant Oxen in catchments such as the River Otter, Devon, from c. 100,000 years B.P. support this assertion. However, it is clear from the palaeoecological data (pollen and beetles) that postextinction of such mega-fauna, mid-Holocene European forests were not open, apart from small windthrow gaps and beaver meadows, and that large, open canopy conditions are only associated with human activity (Svenning, 2002; Whitehouse and Smith, 2004; Mitchell, 2005). Whilst Vera's assessment of the degree of openness of European floodplains can be questioned the reintroducing of such disturbance into floodplains is likely to have major positive ecological effects through creating and enlarging gaps and increasing habitat diversity and heterogeneity. 
A more limited rewilding approach, which has a long history in North America (Keller and Swanson, 1979) has been the deliberate insertion of large woody obstructions to European rivers in order to mimic natural logjams. This insertion of wood has been shown to increase nutrient and biomass flux from the basal resources to invertebrates and thence to fish (Thompson et al., 2017). This approach can also be used to promote recovery in over-widened reaches (Henry et al., 2017), however, the insertion of whole trees into rivers remains a substitute for natural fluvial processes coupled with a forested floodplain and biotic disturbance. Hence by far the most important species reintroduction in European rewilding schemes, in terms of impacts upon the structure and function of streams and rivers has been the European beaver. There have been at least 150 reintroductions of beavers in 24 European countries (BACE, 2017) including; Litovelské Pomoravi (Czech Republic, 1991), Millingerwaard, part of Gelderse Poort (Netherlands, 2014), central and southern Germany, the Brittany Alps, and the Loire (Dewas et al., 2011), Knapdale and Tayside (Scotland , 2009, Gaywood et al., 2015) and Devon (England, Puttock et al., 2017). As a result, the population which fell to not more than 1200 individuals divided in 8 isolated population across Europe (Liarsou, 2013) has now dramatically increased. For example in France at the beginning of the 20th century, only about a hundred beaver remained while, it is considered that today around 20,000 have recolonised $60 \%$ of the French streams (Dubrulle and Catusse, 2012) and even extended into the rivers of the Paris urban area.

\subsection{Rewilding with beavers}

Reintroduction schemes have been prompted, or justified, by the European Habitat Directive (1992) and many are associated with the Rewilding Europe Project (Allen et al., 2017). Early reintroductions, starting in the mid-20th Century focussed upon species conservation, whereas more recent efforts and indeed recent research papers on indigenous beaver populations have recognised the multiple environmental benefits that beaver reintroduction might deliver to riverine ecosystems (John and Klein, 2004; Gaywood et al., 2012; Puttock et al., 2017; Law et al., 2017, Wegener et al., 2017). Ecosystem services that respond positively to beaver reintroduction include; flood attenuation, sediment and carbon storage, water quality improvements and increased biodiversity (Hering et al., 2001). Factors that may be negatively impacted include: local flooding of infrastructure or farmland, which may require mitigation such as beaver dam removal, changes to local sedimentation regime, as areas upstream of dams retain sediment and areas downstream lose sediment and the passage of migratory fish. However, Kemp et al., (2012), review the impact of 
beaver dams on stream fish and conclude that the majority of North American and European experts now consider beaver to have an overall positive impact on fish populations, through their influence on abundance and productivity. Indeed Wegener et al., (2017) demonstrate the potential for wide, multi-thread streams and rivers to act as significant buffers for water, sediment and nutrient storage, once they have been dammed by beaver, particularly at times of high flow. Furthermore, Rosell et al., (2005) argue that protection of ecosystem engineers such as beaver, will allow whole ecosystems to be conserved, as the beaver will modify landscapes to the positive benefit of the wider biodiversity that can be supported. Thus, it is likely that where beaver are reintroduced, positive benefits will accrue and by extension that where they have been removed, negative outcomes have resulted (Halley and Rosell, 2002).

Recent positive changes highlighted in the North American literature referred to above are exemplified by results from the Mid-Devon beaver trial, a scientifically controlled release project, where a pair of beavers were introduced to a wet woodland site in 2011 in the UK (Puttock et al.,

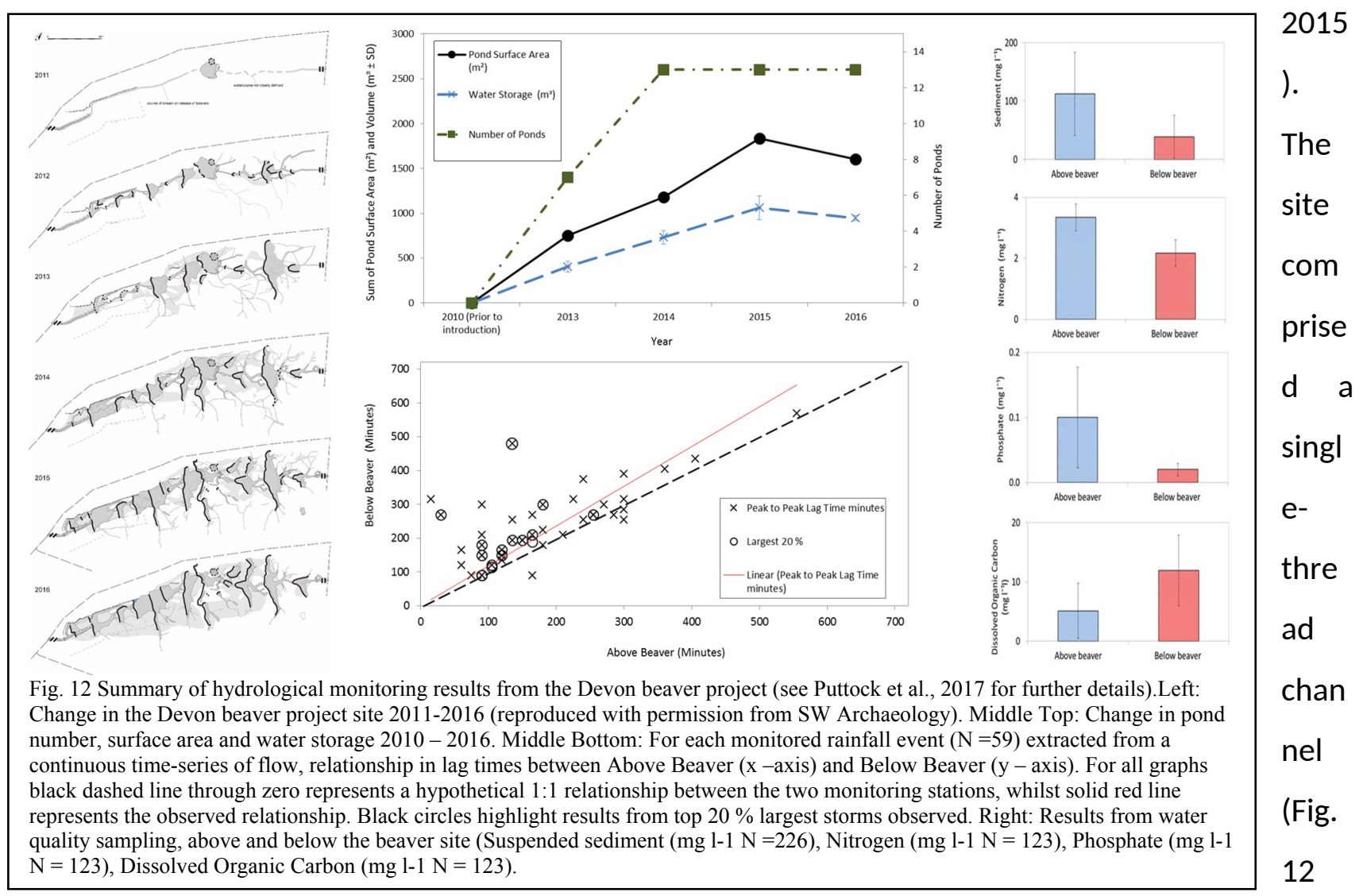

panel a), sourcing from intensive agricultural grassland, with a dense vegetation cover of willow carr, overlying a peaty podzol soil above impermeable shale bedrock. The site was hydrologically isolated around its perimeter such that apart from rainfall, flow into the site only occurred via the 
single-thread channel and flow out of the site left via one channel. These two channels were gauged via installation of v-notch weirs to support flow and water quality measurements, on 15 minute time steps, alongside synchronous measurements of both water table and pond depth. Figure 12 illustrates the significant change in ecosystem structure that ensued. The number of ponds increased from one (man-made to support release of the animals) to 13 , in a 5 year period, with standing surface water extent changing from ca. $90 \mathrm{~m}^{2}$ to a maximum of ca. $1800 \mathrm{~m}^{2}$ representing a volume of ca. $1000 \mathrm{~m}^{3}$ of water stored in beaver ponds. This profound alteration to the structure of a headwater channel system demonstrates the way in which small, headwater floodplains may have existed prior to the human interventions described earlier in this paper. The way in which this channel system now functions, also gives us clues as to how headwater channels, densely dammed by beavers might have behaved. Since beaver damming, the lag times between peak storm flows entering the site and leaving the site are $>1 \mathrm{~h}$, despite the channel length being only $183 \mathrm{~m}$. This 'slowing the flow' impact of beaver damming is not unique (see Law et al., 2016 for another example) and is thought to be a key ecosystem service that humans have removed from channels both by eradicating beavers but also by straightening, deepening and removing vegetation, including woody debris from channel networks (Gurnell et al., 1998). Beaver dams are also leaky, such that water accumulated during storms is released for some time after rainfall ends. This function serves to enhance river baseflows downstream, elevating flow during drought, as storm hydrographs are attenuated due to the complex topography of the beaver-engineered landscape. Water quality is also shown to improve as flow is filtered through beaver dams. Puttock et al., (2017) show $3 \times$ less sediment, $0.7 \times$ less nitrogen and $5 \times$ less phosphate leaves the beaver site than enters, illustrating the role that beaver dams play in mitigating diffuse pollution from agriculture. Finally, biodiversity responds to the creation of beaver dams in a multitude of ways; Bryophytes ( 43 to 55 species), wetland beetles ( 8 to 26 species) and aquatic invertebrates (14 to 41 species) all changed significantly between 2012 and 2015, whilst the number of frogspawn clumps recorded pre-beaver introduction was 10, the number recorded in 2017 was $>650$, with consequent impacts on the trophic cascade including more predators such as kingfisher, heron and egret (Devon Wildlife Trust 2017).

The restoration of some level of pre-anthropogenic structure to streams and rivers, whether vie beaver reintroduction or the construction of large woody dams, or simply floodplain multi-species afforestation offers great potential to address contemporary issues such as downstream flooding 
and diffuse pollution, as well as enhancing biodiversity. Whilst evidence of the positive benefits of beavers (for example) may currently be limited to a small group of papers, the very obvious, degraded state of contemporary streams and rivers, with simplified, within-bank structures, which deliver very few wider ecosystem services, points to the fact that rewilded, perhaps seminaturalised riverine ecosystems could be more beneficial to society.

\section{Implications for Anthropocene River Restoration}

In summary, early-mid Holocene (or pre-deforestation) streams in lowland temperate Europe lacked elevated floodplains, were formed by fine clastic flats and levees with meandering river planforms commonly seen today. Instead they were either braided (in high slope areas) or anabranching/anastomoding wetland or woodland systems. In both cases their geomorphic processes were strongly affected by marginal and within-channel vegetation, in-channel organic sediments and an intermediate disturbance regime. The change in these rivers to their Anthropocene state, started in the Prehistoric period after the adoption of farming in Europe, but was lagged depending upon local circumstances, ranging in date from as early as $6000 \mathrm{BP}$, to the last few hundred years, with some islands of forested-streams persisting. In some cases particularly high rates of late Holocene alluviation have caused relative incision to the point where the floodplain has become a low terrace and is rarely if ever inundated. In most cases overbank sedimentation has buried the organic-rich channel fills, hydric soils, tufas and backswamps of the early-mid Holocene valley floors, creating cohesive river banks and relatively flat inorganic floodplains. It can be shown that the highly sinuous planform of small segments of floodplains are the product of a shrinkage of multi-channel patterns with the preservation of channels crosscutting the floodplain from bifurcation to bifurcation, and have not resulted from active meander migration. Unlike the situation in the mid-Atlantic streams of the United States (Walter and Merritts, 2008) watermills did not cause this transformation but did utilise the (shrinking) multichannel nature of many streams, and may, along with water-meadow systems, have been important in accelerating the processes of local sedimentation and channel stabilisation over the last 1000 years (Beauchamp et al., 2017). There are a few valleys where this process was arrested, either due to soils unsuited to arable cultivation, or due to forest management for the purpose of hunting. These rare systems are important in terms of reference states as they are engineered, but stable, and of high biodiversity (Harper et al., 1997; Beauchamp et al., 2017: Schindler et al., 2016). 
Along with the geomorphic transformation, the riverine ecosystem services including carbon sequestration, of river environments have been changed. The accumulation of dead biomass and formation of peat was a net carbon store which has been replaced by the cycling of predominantly grasslands on clay-rich soils with some arable cultivation. Likewise the hydrological characteristics of the valley floors have changed dramatically with a reduction in overbank storage and faster evacuation of overbank flows from floodplains back into channels.

It is clear from this review that it is impossible to return lowland streams and floodplains of temperate Europe to anything approximating an originally natural state or a hypothetical natural equilibrium condition with reference to a point in time in the past. To even start the process would

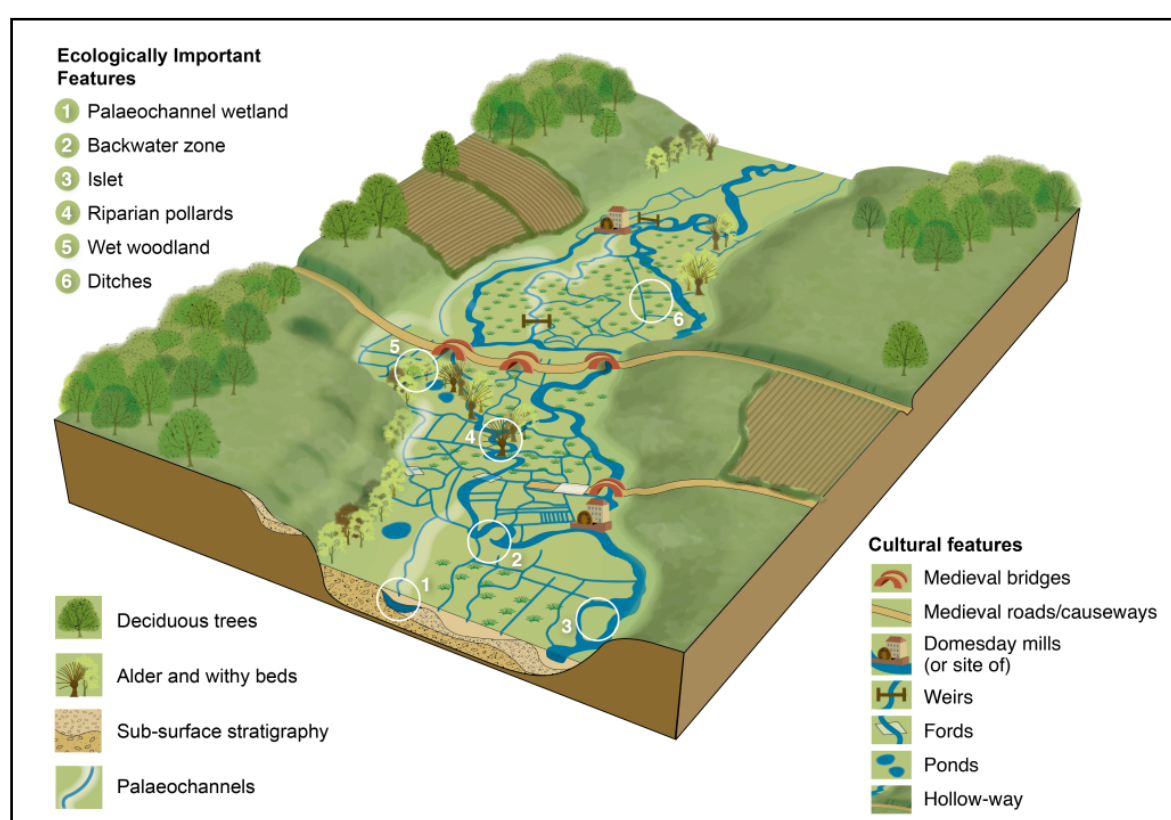

Fig. 13. A RES model for both fluvial and cultural features derived from the lower River Avon in Dorset, England. require the removal of huge quantities of legacy or anthropogenic overbank sediments, which itself would pose a major problem of disposal. It is, nevertheless, possible to recognise complex, oftenmulti-channel systems, which have high biodiversity and channelfloodplain linkage, remnants of which frequently persist and which are often depicted on early maps and which can form planforms for restoration (Oakley, 2010). Geomorphological studies in Europe have identified a number of restoration variants (Lespez et al., 2016) several of which can be adapted to multi-channel patterns and which can maximise both in-channel and riparian biomass and thus make a major contribution to the maintenance of regional biodiversity, one of which is almost certainly to let the beaver do this work which may also be cost-effective. These evidence-based approaches can recognise the cultural component embedded in riverine ecosystem services (Fig. 13) and the spatial implications this has. Restoration should seek to recreate these culturally created semi-impacted systems, remains of which are often still visible (in the field and on early maps), and reconnect the channels 
with as much of the floodplain as is possible in order to achieve gains at the catchment scale (Dixon et al., 2015). To avoid the copy-and-paste approach used in short-term studies which lead too often to truncated specifications and/or failure for restoration projects (Palmer et al., 2009). It is desirable to extend our knowledge on alternative fluvial states and their resilience by including long-term dynamics and evolutionary trajectories (Brierley and Fryirs, 2016; Dearing et al., 2015; Brown et al., 2013; Lespez et al., 2015).

This paper illustrates the lessons that can be learned from the European floodplains concerning the beneficial aspects of landscape history which can improve earth and ecosystem services (e.g. ground and flood-water storage, carbon storage). This should form part of managed floodplain resources as part of responsible stewardship, especially pertinent in the context of European-wide management strategies under the European Water Framework Directive (European Union, 2015). These include the cultural landscapes, such as hay and water-meadows, that are biodiversity gains of the Anthropocene. The enhancement, restoration or rewilding of European floodplains has huge potential for increasing biodiversity across Europe, and is probably the most cost-effective way of conserving iconic and key-stone species. But as pointed out by Schindler et al. (2016). It is also often the most challenging due to the multiplicity of organisations with interests and roles in floodplain governance and management. However, we argue here that we must recognise an additional 'messiness' (Wohl, 2016) from cultural as well as natural features of the waterscape if we are to avoid floodplain nature vs culture conflicts particularly in Europe where the hybrid nature of rivers is the normal case and not the exception.

\section{Acknowledgements}

Many colleagues both in academia and in conservation/environmental organisations must be thanked for assistance in the production of this paper including Mike Clarke (RSPB), Nicki Whitehouse, Steve Davis, Thomas Hoffmann, Mark Macklin, Alan Puttock, Phillip Toms, David Parsons, Finbar McCormick, Patrick Gleeson and Richard Jones. OSL dating from the Severn-Wye Basin was undertaken at the Geochronology Laboratories, University of Gloucestershire under grants from the EU Leader+ Programme (administered by English Heritage) and the Leverhulme Flood and Flow Project (RPG-2016-004).

\section{Appendix A. Supplementary data}

Supplementary data associated with this article can be found in the online version, at 


\section{References}

Aleksandrowicz S.Z., Żurek S., 2005. Landscape and peatlands of the Narew National Park (in Polish). Chrońmy Przyrodę Ojczystą. V.65. 5-19.

Allen, D., Bosmann, I., Helmer, W., Schepers, F., 2017. Rewilding Europe. 2016 Annual Review. Ecoprint, The Netherlands. See also https://www.rewildingeurope.com/.

Alsos, I.G., Sjögren, P., Edwards, M., Landvik, J., Gielly, L., Forwick M., Cossack, E., Brown, A.G., Jacobsen, L. V., Føreid, M. and Pedersen, M., 2016. Sedimentary ancient DNA from Lake Skartjørna, Svalbard: Assessing the resilience of arctic flora to Holocene climate change. The Holocene 25, 1-16.

Assini, A.A., Petiti, F., 1995. Logjam effects on bedload mobility from experiments conducted in a small gravel bed forest ditch. Catena, 25, 117-126.

BACE (Beaver Advisory Committee for England) 2017. https://beaversinengland.com/about/

Baker, A., Simms, M.J., 1998. Active deposition of calcareous tufa in Wessex, UK, and its implications for the 'late-Holocene tufa decline. The Holocene 8, 359-65.

Banaszczuk P., Wołkowycki D., (eds). 2016. The Narew National Park. 2016. Warsaw: Institute of Environmental Protection.

Beauchamp, A., Lespez, L., Rollet, A. J., Germain-Vallée, C., \& Delahaye, D., 2017. Les transformations anthropiques d'un cours d'eau de faible énergie et leurs conséquences, approche géomorphologique et géoarchéologique dans la moyenne vallée de la Seulles, Normandie. Géomorphologie: relief, processus, environnement 2, 121-138.

Beechie, T.J., Sear, D.A., Olden, J.D., Pess, G.R., Buffington, J.M., Moir, H., Roni, P., Pollock, M.M., 2010. Process-based principles for restoring river ecosystems. Bioscience 60, 209-222.

Bennett, J. A., Brown, A. G., Read, S. J., 2014. Exeter and Its River: Late Holocene Fluvial Geomorphology from Archaeology and Historical Sources. Proceedings of the Geologists Association 125, 639-648.

Berendsen HJA, Stouthamer, E. 2001. Palaeogeographic development of the Rhine-Meuse delta, The Netherlands. Assen, Van Gorcum, The Netherlands: 270 pp.

Bloch M., 1935. Avènement et conquêtes du moulin à eau. Annales d'histoire économique et sociale, 7, 36, 538-563 (The advent and triumph of the watermill. In Anderson, JE (Ed.) Land and Work in Medieval Europe: Selected Papers by Marc Bloch. Routledege, London.)

Booth, P, Dodd A, Robinson M, Smith, A., 2007. The Thames Through Time. The Archaeology of the Gravel Terraces of the Upper and Middle Thames: The Early Historical Period: AD1-1000. Oxford Archaeology, Thames Valley Landscape Monograph No. 27, 0-470.

Bos, J.A.A., 2001. Lateglacial and Early Holocene vegetation history of the northern Wetterau and the Amöneburger Basin (Hessen), central-west Germany. Review of Palaeobotany and Palynology 115, 177-212.

Boye, K, Noel, V., Tfaily, M.M., Bone, S.E., Williams, K.H., Barger, J.R., Fendorf, S., 2017. Thermodynamically controlled preservation of organic carbon in floodplains. Nature Geoscience online 
Branch NP, Batchelor CR, Cameron NG, Coope R, Densem R, Gale R, Green CP, Williams, A.N., 2012. Holocene Environmental Changes at Hornchurch Marshes, London, UK: implications for our understanding of the history of Taxus (L.) woodland in the Lower Thames Valley. The Holocene 22, 1143-1158.

Brierley, G. J., Brooks, A. P., Fryirs, K., Taylor, M. P., 2005. Did humid-temperate rivers in the Old and New Worlds respond differently to clearance of riparian vegetation and removal of woody debris? Progress in Physical Geography 23, 27-49.

Brierley GJ, Brooks AP, Fryirs K., 2005. Did humid temperate rivers in the Old and New Worlds respond differently to clearance of riparian vegetation and removal of woody debris? Progress in Physical Geography 29, 27-49.

Brierley, G.J., Fryirs, K.A., 2016. The use of evolutionary trajectories to guide 'moving targets' in the management of river futures. River Research Applications 32, 823-835

Broadmeadow, S., Jones. J.G., Langford, T.E.L., Shaw, P.J. and Nisbet, T., 2010. The influence of riparian shade on lowland stream water temperatures in Southern England and their viability for Brown Trout. River Research and Applications, 27: 226-237. doi:10.1002/rra.1354.

Brookes, A., 1988. Channelised rivers, perspectives in environmental management. Wiley, Chichester.

Broothaerts, N., Verstraeten, G., Notebaert, B., Kasse, C., Bohncke, S,. Assendelft R., Vandenberghe, J., 2012. Humans reshaped the floodplain geoecology in NW Europe through intense agricultural impact. Geophysical Research Abstracts 14, EGU2012-7961-1.

Brown, A.G., 1997a. Alluvial Environments: Geoarchaeology and Environmental Change. Cambridge University Press, Cambridge.

Brown, A.G. 1997b. Biogeomorphology and diversity in multiple-channel systems. Global Ecology and Biogeography Letters 6, 179-185.

Brown, A.G., 1998. The maintenance of biodiversity in multiple-channel floodplains. In R. G. Bailey, P. V. José and B. R. Sherwood (Eds.), United Kingdom Floodplains. Linnean Society, Westbury Press, 83-92.

Brown, A.G., 1999. Characterising Prehistoric lowland environments using local pollen assemblages. Quaternary Proceedings 7: 585-594.

Brown, A.G., Barber, K.E., 1985. Late Holocene palaeoecology and sedimentary history of a small lowland catchment in Central England. Quaternary Research 24, 87102.

Brown, A.G., Harper, D.M., Peterken, G.F., 1997. European floodplain forests: structure, functioning and management. Global Ecology and Biogeography Letters 6, 169-178.

Brown, A. G., Stone, P., Harwood, K., 1995. The Biogeomorphology of a Wooded Anastomosing River: The Gearagh on the River Lee in County Cork, Ireland. Occasional Papers in Geography, No 32, University of Leicester, 76p.

Brown, A.G., Toms P., Carey C., Rhodes E., 2013. Geomorphology of the Anthropocene: time-trangressive discontinuities of human-induced alluviation. The Anthropocene 1, 3-13. 
Brown, A.G., Cooper, L., Salisbury, C.R., Smith, D.N., 2001 Late Holocene channel changes of the Middle Trent: Channel response to a thousand year flood record. Geomorphology 39, 69-82.

Bull, I.D., Lockheart, J., Elhmmali, M.M., Roberts, D.J., Evershed, R.P., 2002. The origin of faeces by means of biomarker detection. Environmental International 27, 647-654.

Cador J.-M., Lespez L., 2012. Entre hydrosystèmes et systèmes hydrauliques : les cours d'eau bas-normands aujourd'hui, In Lespez L. (ed.), Paysages et gestion de l'eau : sept millénaires d'histoire des basses vallées en Normandie. Bibliothèque du Pôle Rural 3, MRSH Caen-Presses Universitaires de Caen, 233-271.

Cai, P., Huang, Q-Y.,Zhang, X-W., 2006. Interactions of DNA with Clay Minerals and Soil Colloidal Particles and Protection against Degradation by DNase. Environ. Sci. Technol. 40, 2971-2976.

Coles, B.J. 1994. Trisantona river: a landscape approach to the interpretation of river names. Oxford Journal of Archaeology 13, 295-311.

Coles, B.J., 2006. Beavers in Britain's Past. WARP Occasional Paper 19. Oxbow Books, Oxford.

Collins, A.L., Walling, D.E., 2007. Fine-grained bed sediment storage within the main channel systems of the Frome and Piddle catchments, Dorset, UK. Hydrological Processes 21, 1449-1459.

Cooke, H., Williamson, T., 2007. Water Meadows: History, Ecology and Conservation. Windgather Press, Oxford, UK.

Comiti, F. 2012. How natural are Alpine mountain rivers? Evidence from the Italian Alps. Earth Surface Processes and Landforms 37, 693-707.

Darby, S., Sear, D.A., 2008. River Restoration: managing the Uncertainty in Restoring Physical Habitat. Wiley, Chichester, UK.

Davies, N.S., Gibling, M.R., 2011. Evolution of fixed-channel alluvial plains in response to Carboniferous vegetation. Nature Geosciences 4, 629-633.

Davis, S.R., Brown, A.G., Dinnin, M.H. 2007. Floodplain connectivity, disturbance and change: A palaeoentomological investigation of floodplain ecology from SW England. Journal of Animal Ecology 76, 276-288.

D'Anjou, R.M., Bradley R.S., Balascio N.L., et al., 2012. Climate impacts on human settlement and agricultural activities in northern Norway revealed through sediment biogeochemistry. Proceedings of the National Academy of Sciences of the United States of America 109, 20332-20337.

Dearing, J.A., Yang, X., Dong, X., Zhang, E., Chen, Xu., Langdon P.G., Zhang K., Zhang W, Dawson, T.P., 2012. Extending the timescale and range of ecosystem services through paleoenvironmental analyses exemplified in the lower Yangtze basin. PNAS E1111-E1120.

DEFRA, 2015. Catchment Restoration Fund: Environment Agency Final Annual Report 2014-2015. Department of Environment Food and Rural Affairs, UK Government, London.

De Moor, J.J.W., Van Balen, R.T., Kasse, C., 2007. Simulating meander evolution of the Geul River (the Netherlands) using a topographic steering model. Earth Surface Processes and Landforms 32, 1077-1093. 
De Moor, J., Verstraeten, G., 2008. Alluvial and colluvial sediment storage in the Geul River catchment (The Netherlands): combining field and modelling data to construct a Late Holocene sediment budget, Geomorphology 95, 487-503.

Devon Wildlife Trust, 2017. Beavers - Natures Water Engineer's: A summary of the initial findings from the Devon Beaver projects. Devon Wildlife Trust, Exeter, UK.

Dewas, L., Herr, J., Schly, L., Catusse, M., 2011. Recovery and status of native and introduced beavers Castor fiber and Castor canadensis in France and neighbouring countries. Mammal Review 42, 1-22.

Dinin, M., Brayshay, B., 1999. The contribution of a multiproxy approach in reconstructing floodplain development. Geological Society, London, Special Publications, 163, 179-195.

Dixon, S.J., Sear, D.A., 2014. The influence of geomorphology on large wood dynamics in a low-gradient headwater stream. Water Resources Research 50, 9194-9210.

Dixon, S.J., Sear, D.A., Odoni, N.A., Sykes, T., Lane, S.N., 2016. The effects of river restoration on catchment scale flood risk and flood hydrology. Earth Surf. Process. Landforms 41, 997-1008

Dolédec, S., Forcellini, M., Olivier, J-M., Roset, N., 2016. Effects of large river restoration on currently used bioindicators and alternative metrics. Freshwater Biology 60, 1221-1236.

Dotterweich, M., 2008. The history of soil erosion and fluvial deposits in small catchments of central Europe. Deciphering the long-term interactions between humans and the environment: A review. Geomorphology 101, 192-208.

Downward, S., Skinner, K., 2005. Working rivers: the geomorphological legacy of English freshwater mills. Area 37, 138-147.

Dubrulle P.-M., Catusse M., 2012. Où en est la colonisation du Castor en France? Faune.Sauvage 297, 24-35.

Ejarque, A. Beauger, A, Miras, Y., Peiry, J-L., Voldoire, O., Vautier, F.Benbakkar, M., Steiger, J., 2015. Historical fluvial palaeodynamics and multi-proxy palaeoenvironmental analyses of a palaeochannel, Allier River, France, Geodinamica Acta, 27, 25-47.

Ekwall, E., 1928. English Rivernames. Oxford at the Clarendon Press, Oxford, UK, 488pp.

European Union (2015) The fourth implementation report - assessment of the Water Framework Directive Programmes of Measures and the Flood Directive. March 2015, Brussels. Z

Felix-Henningsen, P., 1984. Zur Relief-und Bodenentwicklung der Goz-Zone Nordkordofans im Sudan. Zeitschrift fur Geomorphol. N. F. 28, 285-303.

Finance Act (France) 2017.

https://www.performancepublique.budget.gouv.fr/sites/performance_publique/files/farandole/ressources/ 2017/pap/pdf/jaunes/Jaune2017_agences_eau.pdf).

Flood and Flow, 2017. https://www2.le.ac.uk/departments/history/research/grants/flood-and-flow-placenames-and-the-changing-hydrology-of-river-systems/floodandflow). 
Florsheim, J.L., Mount, J.F., 2003. Changes in lowland floodplain sedimentation processes: pre-disturbance to post-rehabilitation, Cosumnes River, California. Geomorphology 56, 305-323.

Florsheim, J.L. Mount, J.F., Hammersmark, C., Fleenor, W.E., Schladow S.G., 2008. Geomorphic influence on flood hazards in a lowland fluvial-tidal transitional area, Central Valley, California. Natural Hazards Review 9 , 116-124.

Florsheim, J.L., Pellerin B., Oh, N.H., Ohara, N., Bachand, P., Bachand, S., Bergamaschi, B., Hernes, P.B. Kavvas, M.L., 2011. From deposition to erosion: spatial and temporal variability of sediment sources, storage, and transport in a small agricultural watershed. Geomorphology 132, 272-286.

Francis, R.A., Petts, G.E. \& Gurnell, A.M., 2008. Wood as a driver of past landscape change along river corridors, Earth Surface Processes and landforms, 33, 1622-1626.

František, J., Baker, S., Kostkan, V., 2010. Habitat selection of an expanding beaver (Castor fiber) population in central and upper Morava River basin. European Journal of Wildlife Research 56, 663-671.

French, C., 2003. Geoarchaeology in Action. Routledge, London.

Gaywood, M. (Ed.), 2017. Beavers in Scotland. A Report to the Scottish Government. Scottish Natural Heritage, Edinburgh.

Gelling, M. 1984. Place-Names in the Landscape: The Geographical Roots of Britain's Place-names. London, J.M. Dent \& Son.

Gelling, M., Cole, A., 2000. The Landscape of Place-Names. Shaun Tyas, UK.

Giguet-Covex, C., Pansu, J., Arnaud, F., Rey, P-J., Griggo, C., Gielly, L., Domaizon, I., Coissac, E., David, F., Choler, P., Poulenard, J., Taberlet, P., 2014. Long livestock farming history and human landscape shaping revealed by lake sediment DNA. Nature Communication 5, 3211.

Girel, J., 1994. Old distribution procedures of both water and matter fluxes in floodplains of western Europe: impact on present vegetation. Environmental management 18, 203-221.

Gradziński, R., Baryla, J., Danowski, W., Doktor, M., Gmur, D., Gradziński, M., Kedzior, A., Paslowski, M., Soja, R., Zieliński, T., Zurek, S., 2000. Anastomosing systems of the upper Narew River, NE Poland. Annales Societatis Geologorum Poloniae 70, 219-229.

Grant, M.J., Hughes, P.D.M., Barber, K.E. 2014. Climatic influence upon early to mid-Holocene fire regimes within temperate woodlands: a multi-proxy reconstruction from the New Forest, southern England. Journal of Quaternary Science 29, 175-188.

Gregory, K.J., Davies, R.J., Tooth, S., 2003. Spatial distribution of coarse woody debris dams in the Lymington Basin, Hampshire, UK, Geomorphology 6, 207-224.

Gregory, K.J., Starkel, L., Baker, V.R., (Eds.) 1995. Global Continental Palaeohydrology. John Wiley and Sons, Chichester, p334.

Gurnell, A.M., 1998. The hydrogeomorphological effects of beaver dam-building activity. Progress Physical Geography 22, 167-189. 
Gurnel,I A.M., Petts, G.E., 2002. Island-dominated landscapes of large floodplain rivers, a European perspective. Freshwater Biology 47: 581-600.

Hagedorn, J., Rother, N., 1992. Holocene floodplain evolution of small rivers in the uplands of Lower Saxony. Geomorphology 4, 423-432.

Halley, D., Rosell, F., 2002. The beaver's reconquest of Eurasia: status, population development and management of a conservation success. Mammal Review 32, 153-178.

Halley, D.J., Rosell, F., 2003. Population and distribution of European beavers (Castor fiber). Lutra 46, 91101.

Happ, S.C., Rittenhouse, G., Dobson, G.C., 1940. Some principles of accelerated stream and valley sedimentation. United States Department of Agriculture Technical Bulletin 695.

Harper, D., Mekotova, J., Hulme, S., White, J., 1997. Habitat heterogeneity and aquatic invertebrate diversity in floodplain forests. Global Ecology and Biogeography Letters 6, 275-285.

Harvey, G.L., Henshaw, A.J., Parker, C., Sayer, C.D., 2017. Re-introduction of structurally complex wood jams promotes channel and habitat recovery from overwidening: Implications for river conservation. Aquatic Conservation: Marine Freshwater Ecosystems 2017, 1-13.

Harwood, K., Brown, A. G., 1993. Changing in-channel and overbank flood velocity distributions and the morphology of forested multiple channel (anastomosing) systems. Earth Surface Processes and Landforms 18, 741-748.

Hayhow, D.B., Bond, A.L., Douse,A., Easton,M.A., Frost,T., Grice,P.V., Hall,C., Harris,S.J., Havery,S., Hearn,R.D., Noble,D.G., Oppel,S., Williams,J., Win, I., Wolton, S., 2017. The Status of UK's Birds. BTO, RSPB, DAERA, JNCC, NE, NRW, SNH, Sandy, Berkshire 48p.

Harbert, P.D.N., Cywinska, A., Ball, S.L., deWaard, J. R., 2003. Biological identifications through DNA barcodes. Procs. Roay. Soc. B. 270, 137-149.

Heck, H., 1951. The Breeding-Back of the Aurochs. Oryx. 1, 117.

Helfield, J.M., Engström, J., Michel, J.T., Nilsson, C., Jansson, R., 2012. Effects of river restoration on riparian biodiversity in secondary channels of the Pite River, Sweden. Environmental Management 49(1), 130-41.

Hering, D., Gerhard, M., Keil, E., Ehlert, T., Pottgiesser, T., 2001. Review Study on Near-natural Conditions of Central European Mountain Streams, with Particular Reference to Debris and Beaver Dams: Results of the "REG Meeting" 2000. Limnologica 31, 81-92.

Hoffmann, T.O., Glatzel, S., 2007. A carbon storage perspective on alluvial sediment storage in the Rhine catchment. Geophysical Research Abstracts, Vol. 9

Hoffmann, T., Lang, A., Dikau, R., 2008. Holocene river activity: analysing 14C-dated fluvial and colluvial sediments from Germany. Quaternary Science Reviews 27, 2031-2040.

Hohensinner, S., Habersack, H., Jungwirth, M., Zauner, G., 2004. Reconstruction of the characteristics of a natural alluvial river-floodplain system and hydromorphological changes following human modifications: the Danube River (1812-1991). River Research and Applications 20, 5-41. 
Houben, P., 2007. Geomorphological facies reconstruction of Late Quaternary alluvia by the application of fluvial architecture concepts. Geomorphology 86, 94-114.

Houben, P., Schmidt, M., Mauz, B., Stobbe, A., Lang, A., 2013. Asynchronous Holocene colluvial and alluvial aggradation: A matter of hydrosedimentary connectivity. The Holocene 23, 544-555.

Huntley, B., Birks, H.J.B., 1983. An atlas of past and present pollen maps for Europe: 0-13 000 years ago. Cambridge University Press, Cambridge.

Jeffries R., Darby S.E., Sear D.A., 2003. The influence of vegetation and organic debris on flood-plain sediment dynamics: case study of a low-order stream in the New Forest, England. Geomorphology 51, 61-80.

John, S., Klein, A., 2004. Hydrogeomorphic effects of beaver dams on floodplain morphology: avulsion processes and sediment fluxes in upland valley floors (Spessart, Germany). Quaternaire 15, 219-231.

Johnstone, E., Macklin, M.G., Lewin, J., 2006. The development and application of a database of radiocarbondated Holocene fluvial deposits in Great Britain. Catena 66, 14-23.

Jones, R., Gregory, R., Kilby, S., Pears, B., 2017. Living with a trespasser: riparian names and medieval settlement on the River Trent floodplain', European Journal of Post-Classical Archaeologies 7, 61-92.

Keller, E.A., Swanson,F.J.. 1979. Effects of large organic material on channel form and fluvial processes. Earth Surface Processes and Landforms 4, 361-380.

Kemp, P. S., Worthington, T. A., Langford, T. E. L., Tree, A. R. J., Gaywood, M. J., 2012. Qualitative and quantitative effects of reintroduced beavers on stream fish. Fish and Fisheries, 13, 158-181.

Klimenko, V., 2012. Climate fluctuation and colonization of North-Eastern Europe (8th-13th Centuries), (in Russian). Russia and Germany 2, 80-85.

Kostkan, V., Lehký, J., 1997. The Litovelské Pomoraví floodplain forest as a habitat for the reintroduction of the European beaver (Castor fiber) into Czech Republic. Global Ecol Biogeogr 6, 307-310.

Kondolf, M., 2006. River restoration and meanders. Ecology and Society 11, 42.

Kreiner, R., 1996. Städte und Mühlen im Rheinland. Aachener Studien zur älteren Energiegeschichte 5, Aachen, Historisches Institut Lohrmann, D. Hg., 0-49.

Law, A., McLean, F., Wilby, N.J., 2016. Habitat engineering by beaver benefits aquatic biodiversity and ecosystem processes in agricultural streams. Freshwater Biology 61, 486-499.

Lechner, A., 2009. Palaeohydrologic conditions and geomorphic processes during the Postglacial in the Palatine Upper Rhine river floodplain. Z. Geomorpholgie N. F. 53, 2 217-245.

Leopold, L.B., Wolman, M.G., 1957. River channel patterns: braided, meandering and straight. United States Geological Survey Professional Paper 282C, 1-85.

Lespez, L., Germaine, M-A., 2016. La rivière désaménagée? Leas paysages fluviaux et l'effacement des seuils et des barrages en Europe de l'ouest et en Amerique du nortd-est. BSGLg 67, 37-68. 
Lespez, L., Viel, V., Rollet, A-J., Delahaye, D., 2015. The anthropogenic nature of present-day low energy rivers in western France and implications for current restoration projects. Geomorphology 251, 64-76.

Lespez, L., Clet-Pellerin, M., Limondin-Lozouet, N., Pastre J-F., Fontugne, M., Marcigny, C., 2008. Fluvial system evolution and environmental changes during the Holocene in the Mue valley (W France).

Geomorphology 98, 1-2, 55-70.

Lespez L., Viel V., Cador J.-M., Germaine M.-A., Germain-Vallée C., Rollet A.-J., Delahaye D., 2013.

Environmental dynamics of small rivers in Normandy (western France) since the Neolithic era. What lessons for today in the context of the European Water Framework Directive? In Arnaud-Fassetta G. Massson E., Reynard E., (Eds). European Continental hydrosystems under Changing water policy, Pfeil, Munich, 113-124.

Lespez L., Germaine M.-A., Barraud R., 2016. L'évaluation par les services écosystémiques des rivières ordinaires est-elle durable ? VertigO URL : http://vertigo.revues.org/17443

Lewin J., 2010. Medieval environmental impacts and feedbacks: the lowland floodplains of England and Wales. Geoarchaeology 25, 267-311.

Lewin, J., 2013. Enlightenment and the GM floodplain. Earth Surface Processes and Landforms 38, 17-29.

Liarsou A., 2013. Interactiosn between the beaver (Castor fiber L.) and human societies. Archaeological review from Cambridge, 28, 2, 171-185.

Liarsou, A., 2001. Le castor et l'homme d'hier à ajourd'hui. I'Harmattan, Paris 320p.

Lobb, M.A., 2017. Developing Terrestrial Laser Scanning of Threatened Coastal Archaeology Sites with a Special Reference to Intertidal Structures. Unpub. PhD Thesis, University of Southampton.

Lobb, M.A., Brown, A.G., Leyland, J., Bernard, V. Subm. TLS Scanning Inter-tidal Structures with Special Reference to Threatened Fixed Fishing and Allied Structures in the Léguer Estuary, Brittany. Journal of Archaeological Science

Lohrmann, D., 1984. Mühlenbau, Schiffahrt und Flussumleitungen im Süden der Grafschaft Flandern-Artois (10.-11. Jahrhundert). Francia 12, Paris, DHI: 149-192.

Lohrmann, D., 1989. Le moulin à eau dans le cadre de l'e'conomie rurale de la Neustrie. In Atsma, H. (ed.), La Neustrie: les pays au nord de la Loire de 650 à 850. Beihefte der Francia 16, Sigmaringen, 367-404.

Logainm.ie, 2018. https://www.logainm.ie/ga/10123?s=Gaorthadh+an+R\%c3\%b3istigh

Lüttig, G., 1960. Zur Gliederung des Auelehms im Flußgebiet der Weser. Eiszeitalter u. Gegenwart 11, 39-50.

Lüscher, A., Daepp, M., Blum, H., Hartwig, E., Nösberger, J., 2004. Fertile temperate grassland under elevated atmospheric $\mathrm{CO} 2$ - role of feed-back mechanisms and availability of growth resources. European Journal of Agronomy 21, 379-398.

Macaire, J-J., Di-Giovanni, C., Hinschberger, F., 2005. Relations entre production organique et apports terrigènes dans les sediments fluviatiles holocènes: observations et interpretations hétérodoxus. Comptes Rendus des Geosciences 337, 735-744. 
Macaire, J-J., Bernard, J., Di-Giovanni, C., Hinschberger, F., Limondin-Lozouet, N., Visset, L., 2006.

Quantification and regulation of organic and mineral saedimentation in a late-Holocene floodplain as a result of climatic and human impacts (Taligny marsh, Parisian Basin, France). The Holocene 16, 647-658.

Machar, I., 2008a. Floodplain forests of Litovelské Pomoraví and their management. Journal of Forest Science 54, 355-369.

Machar, I. 2008b. A proposed target state for a floodplain forest ecosystem within an ecological framework, with reference to the ecological requirements of an umbrella bird species: the common kingfisher. Journal of Landscape Ecology 1,

Macklin, M.G., Jones, A.F., Lewin, J., 2010. River response to rapid Holocene environmental change: evidence and explanation in British catchments, Quaternary Science Reviews 29, 1555-1576.

Macklin, M.G., Lewin, J., Jones, A.F., 2014. Anthropogenic alluvium: an evidence based meta-analysis for the UK Holocene. Anthropocene 6, 26-38.

Meyers, P.A., 2003. Applications of Organic Geochemistry to Paleolimnological Reconstructions: A Summary of Examples from the Laurentian Great Lakes. Organic Geochemistry, 34, 261-289.

Mason, D.C., Horritt, M.S., Hunter, N.M., Bates, P.D., 2007. Use of fused airborne scanning laser altimetry and digital map data for urban flood modelling. Hydrological Processes 21, 1436-1477.

Merritts, D., Walter, R., Rahnis, M., Hartranft, J., Cox, S., Gellis, A., Potter, N., Hilgartner, W., Langland, M., Manion, L., Lippincott, C., Siddiqui, S., Rehman, Z., Scheid, C., Kratz, L., Shilling, A., Jenschke, M., Reed, A., Matuszewski, D., Voli, M., Datin, K., Ohlson, E., Neugebauer, A., Ahamed, A., Neal, C., Winter, A., and Becker, S., 2011. Anthropocene streams and base-level controls from historic dams in the unglaciated mid-Atlantic region, USA. Philosophical Transactions Royal Society A, 369, 1-34.

Mills, A.D., 2011. A dictionary of British placenames. Oxford University Press, Oxford.

Mitchell, F., 2005. How open were European primeval forests? Hypothesis testing using palaeoecological data. Journal of Ecology 93, 168-177.

Mojski J.E., 2005. The Polish territory during the Quaternary. (in Polish). PIG Warszawa.404p.

Montgomery D.R., Abbe T.B., 2006. Influence of logjam-formed hard points on the formation of valleybottom landforms in an old-growth forest valley, Queets River, Washington, USA, Quaternary Research, 65, 147-166.

Mordant, D., Mordant, C., 1992. Noyen-sur-Seine: a Mesolithic waterside settlemnt. In B. Coles (Ed.) The Wetland Revolution in Prehistory. Wetland Archaeological Research Project Occasional Paper 6, Exeter, 5564.

Morandi, B., Piégay, H., 2011. Les restaurations de rivières sur Internet: premier bilan, Nature, Sciences, Société 19, 224-235.

Moss, T., Monstadt, J., (Eds.) 2008 Restoring Floodplains in Europe. IWA Publishing.

Munro, J.H., 2002. Industrial energy from water-mills in the European economy, 5th to 18th 
Centuries: the limitations of power. Munich Personal RePEc Archive (MPRA), 223-1048. Online at https://mpra.ub.uni-muenchen.de/11027/

Natermann, E., 1941. Das Sinken der Wasserstände der Weser und ihr Zusammenhang mit der Auelehmbildung des Wesertales. Arch. Landes- u. Volkskde. Niedersachsens 9, 288-309.

Nilsson, C., Reidy, C.A., Dynesius, M., Revenga, C., 2005. Fragmentation and Flow Regulation of the World's Large River Systems. Science 308, Issue 5720, 405-408.

Notebaert, B., Verstraeten, G., 2010. Sensitivity of West and Central European river systems to environmental changes during the Holocene: A review. Earth-Science Reviews 103, 163-182.

Oakley, S., 2010. Turning back the clock. River Restoration News 35, 2-3ecosystem

Open Domesday Project 2017. http://www.windmillworld.com/watermills/domesday.htm

Palmer, M.A., Mennizer, H.C., Bernhardt, E.S., 2009. River restoration, habitat heterogeneity and biodiversity: a failure of theory or practice. Freshwater Ecol. 55 (suppl.), 1-18.

Pers. com. 2016. Based on official planning estimates from North Rhine-Westphalia with $17 \mathrm{M}$ population and $34000 \mathrm{~km} 2$ for the period 2010-2015.

Parducci, L., Väliranta, M., Salonen, J.S.4, Ronkainen,T., Matetovici, I., Fontana, S.L., Eskola, T., Sarala, P., Suyama, Y., 2015. Proxy comparison in ancient peat sediments: pollen, macrofossil and plant DNA. Philosophical Transactions Royal Society B 370, 2013-382.

Pastre, J-F., Limondin-Lozouet, N., Gebhardt, A., Leroyer, C., Fontugne, M., Krier, V., 2001. Lateglacial and Holocene fluvial records from the central part of the Paris Basin (France). In: Maddy D, Macklin MG, Woodward JC (Eds.), River Basin Sediment Systems - Archives of Environmental Change, Rotterdam Balkema, 357-37.

Peberdy, R.B., 1996. Navigation on the River Thames between London and Oxford in the late Middle ages: a reconsideration. Oxoniensia $65,324-328$.

Peeters, J.H.M., 2007. Hoge Vaart-A27 in Context: Towards a model of Mesolithic-Neolithic land use dynamics as a framework for archaeological heritage management. Rijksdienst voor Arceolgie, Cultuurlandschap en Monumentum Amerfoort.

Petts, G.E., Möller, H., Roux, A.L., 1989. Historical Changes of Large Alluvial Rivers: Western Europe. Wiley, Chichester, UK.

Peust, C., 2015. How Old Are the River Names of Europe? A Glottochronological Approach. Linguistik online 70, $1 / 15$ ? http://dx.doi.org/10.13092/lo.70.1749.

Puttock, A.K., Cunliffe, A., Anderson, K.A., Brazier, R.E., 2015. Aerial photography collected with a multirotor drone reveals impact of Eurasian beaver reintroduction on ecosystem structure. Journal of Unmanned Vehicle Systems 3, 123-130.

Puttock, A.K., Graham, H.A., Cunliffe, A.M., Elliott, M., Brazier, R.E., 2017. Eurasian beaver activity increases water storage, attenuates flow and mitigates diffuse pollution from intensively-managed grasslands.

Science of The Total Environment 576, 430-443. 
Ramade, F., 2003. Eléménts d'ecologie. Dunod, Paris.

Rawlence, N., Lowe, D.J., Wood, J.R., Young, J.M., Churchman, G.J., Huang, Y-T., Cooper, A., 2014. Using palaeoenvironmental DNA to reconstruct past environments: progress and prospects. J. Quat. Sci. 29, 610626.

Reynolds, T.S., 1983. Stronger than a Hundred Men: A History of the Vertical Water Wheel. Baltimore, London.

Ricker, M.C., M.H. Stolt, M.C., Donohue, S.W., Blazejewski, G.A., Zavada, M.S. 2013. Soil organic carbon pools in riparian landscapes of southern New England. Soil Science Society America Journal 77, 1070-1079.

Rittweger, H., 2000. The "Black Floodplain Soil" in the Amöneburger Becken, Germany: a lower Holocene marker horizon and indicator of an upper Atlantic and Subboreal dry period in Central Europe. Catena 41, 143-164

River Restoration Centre, 2002. Handbook of River Restoration Techniques. River Restoration Centre, UK.

Robinson, M.A., 1992. Environment, archaeology and alluvium on the river gravels of the South Midlands In S. P. Needham and M. G. Macklin (Eds.) Alluvial Archaeology in Britain, Oxbow Monograph 27, Oxford, 197208.

Roni, P., Beechie, T., 2013. Stream Watershed Restoration: A Guide to Restoring Riverine Processes and Habitats (Advancing River Restoration and management). Wiley-Blackwell, Chichester, UK.

Rosell, F., Boysér, O., Collen, P., Parker, H., 2005. Ecological impact of beavers Castor fiber and Castor canadensis and their ability to modify ecosystems. Mammal Review 35, No. 3\&4, 248-276.

Rouillard, J., 1996. Moulins hydrauliques du Moyen Age. L'apport des comptes des chanoines de Sens, XVe siècle. Histoire patrimonie, Paris, Vulcain, 0-95.

Schepers, F., Jepson, P., 2016. Rewilding in the European context. International Journal of Wilderness 22, 2530.

Schindler, S., O’Neill, FH., Biró, M., Damm, C., Grasso, V., Kanka, R., van der Sluis, T., Krug, A., Lauwaars, SG., Pusch, M., Baranovsky, B., Ehlert, T., Neukirchen, B., Martin, JR., Euller, K., Mauerhofer, V., Wrbka, T., 2016. Multifunctional floodplain management and biodiversity

effects: a knowledge synthesis for six European countries. Biodiversity Conservation 25, 1349-1382.

Sear, D.A., Millington, C., Kitts, D.R., Jeffries, R., 2010. Logjam controls on channel:floodplain interactions in wooded catchments and their role in the formation of multi-channel patterns, Geomorphology, 116, 305319.

Sidell, J., (Ed.) 2000. The Holocene evolution of the London Thames. Archaeological excavations (1991-1998) for the London Underground Limited Jubilee Line Extension Project. Museum of London Archaeology Service Monograph no. 5.

Sieczko, A.K., Demeter, K., Singer, G.A., Tritthart, M., Preiner, S., Mayr, M., Meister, K., Peduzzi, P., 2016. Aquatic methane dynamics in a human-impacted river-floodplain of the Danube. Limnol. Oceanogr. 61, 2016, 175-187. 
Smith, D., 2000. Disappearance of elmid 'riffle beetles' from lowland river systems - the impact of alluviation. In T O'Connor, R Nicholson (eds.), People as an Agent of Environmental Change. (AEA symposia no. 16). Oxford: Oxbow Books, 75-80.

Stallard, R.F. 1998. Terrestrial sedimentation and the carbon cycle: Coupling weathering and erosion to carbon burial. Global Biogeochemical Cycles 12, 231-257.

Starkel, L., Gregory, K. J., Thornes, J. B., (Eds) 1991. Temperate Palaeohydrology. John Wiley and Sons, Chichester.

Starkel, L., Kalicki, T., Krąpiec M., Soja, R., Gębica P., Czyżowska E., 1996. Hydrological changes of valley floor in the Upper Vistula basin during Late Vistulian and Holocene. In L. Starkel (Ed.), Evolution of the Vistula river valley during the last 15000 years. Quaestiones Geographicae, Special Issue 9, 7-128.

Stobbe, A., 1996. Die holozäne Vegetationsgeschichte der nördlichen Wetterau - paläo-ökologische Untersuchungen unter besonderer Berücksichtigung anthropogener Einflüsse. Dissertationes Botanicae 260, Berlin, 0-216.

Stobbe, A., 2012. Die Jahrtausende um Christi Geburt (1000 BC-1000 AD) - pollenanalytische Untersuchungen im mittleren Lahntal zwischen Wetzlar und Gießen. BerRGK 67, 2011, 32-56.

Strandberg, S., 2015. River names. In C. Hough (Ed.) The Oxford Handbook of Names and Naming. Oxford University Press, Oxford 105-114.

Steinle, A.,Herbener, M. 2016. Die Floßbarmachung der Kinzig am Beispiel historischer Schwallungen: Auswirkungen auf die Gewässerökologie in Vergangenheit und Gegenwart sowie zukünftige Erhaltungs- und Nutzungspotentiale. Berichte der Naturforschenden gesellschaft Freiburg i.Br. 106, Freiburg, pp. 101-128.

Suftin, N.A., Wohl, E., Dwire, K.A., 2016. Banking carbon: a review of organic storage and physical factors influencing retention in floodplain and riparian ecosystems. Earth Surface Processes and Landforms 41, 3860.

Svenning, J-C., 2002. A review of natural vegetation openness in north-western Europe. Biological Conservation 104, 133-48.

Taberlet, P., Coissac, E., Pompanon, F., Gielly, L., Miguel, C., Valentini, A., Vermat, T., Carthier, G., Brochmann, C., Willeslev, E., 2007. Power and limitations of the chloroplast trnL (UAA) intron for plant DNA barcoding. Nucleic Acids Research 35, e14.

Tal M., Gran, K., Murray, A.B., Paol,a C., Hicks, D.M., 2004. Riparian vegetation as a primary control on channel characteristics in multi-thread rivers. In Riparian Vegetation and Fluvial Geomorphology, Bennett, S.J,, Simon, A, (eds). American Geophysical Union: Washington, DC; 43-58.

The Magna Carta Project. 2017. http://magnacarta.cmp.uea.ac.uk/about/aboutproject\#

Thompson, M.S.A., Brooks,S.J., Sayer,C.D., Woodward, G., Axmacher,J.C., Perkins,D.M., Gray,C., 2017. Large woody debris "rewilding" rapidly restores biodiversity in riverine food webs. J Appl Ecol. 201, ;00, 1-10.

Thorp, J.H., Thoms, M.C., Delong, M.D., 2006. The riverine ecosystem synthesis: Biocomplexity in river networks across space and time. River Research and Applications 22, 123-147. 
Törnlund, E., Östlund, L., 2002. Floating timber in Northern Sweden: The construction of floatways and transformation of rivers. Environment and History 8, 85-106.

Trimble, S.W., 1981. Changes in sediment storage in the Coon Creek basin, Driftless Area, Wisconsin., 1853 to 1975 . Science $214,181-183$.

Tubbs, C.R., 2001. The New Forest: history, ecology and conservation. New Forest Ninth Century Trust, New Forest Museum: Lyndhurst, Hampshire, UK. 230pp.

Ustrnul Z., Czekierda D., 2009. Atlas of extreme meteorological phenomena and synoptic situations in Poland. IMGW Warszawa. 1-182.

Václav, S., Lenka, T., Pavel, M., Klára, V., 2016. Deposits and evolution of the alluvial infill on the confluence of Roklanský Potok and Javoří Potok streams at the Šumavské Pláně plains. Silva Gabreta 22, 17-29.

Vettori, C., Paffetti, D., Pietramellara, G., Stozky, G., Gallori, E., 1996. Amplification of bacterial DNA bound on clay minerals by the random amplified polymorphic DNA (RAPD) technique. FEMS Microbiology Ecology 20, 251-260.

Vera, F.W.M., 2000. Grazing Ecology and Forest History. CABI, Wallingford.

Vince, J. 1984. Discovering watermills. 4th edn. Shire Publications Ltd, Tring, UK.

Walter, R.C., Merritts, D.J., 2008. Natural streams and the legacy of water-powered mills. Science 319, 299304.

Wegener, P., Covino, T., Wohl, E. 2017. Beaver-mediated lateral hydrologic connectivity, fluvial carbon and nutrient flux, and aquatic ecosystem metabolism. Water Resources Research, 10.1002/2016WR019790

Wells, C.E., Hodgkinson, D., Huckerby, E., 2000. Evidence for the possible role of beaver (Castor fiber) in the prehistoric ontogenesis of a mire in northwest England, UK. The Holocene. 10, 503-508.

Whitehouse, N.J., Smith, D.N., 2004. 'Islands' in Holocene forests: Implications for Forest Openness, Landscape Clearance and 'Culture-Steppe' Species. Journal of Environmental Archaeology 9, 203-212.

Wohl, E., 2016. Messy rivers are healthy rivers: The role of physical complexity in sustaining ecosystem processes. In G. Constantinescu, Garcia, M., Hanes, D. (Eds.) River Flow 2016

Taylor \& Francis Group, 24-29.

Wohl, E., Hall, R.O., Lininger,K.B., Sutfin,N.A., Walters, D.M., 2017. Carbon dynamics of river corridors and the effects of human alterations. Ecological Monographs 87, 379-409.

Wolman, M.G., Leopold, L.B., 1957.River floodplains: some observations on their formation. United States Geological Survey Professional Paper 282C, 87-107.

Yanson, K.K., Steck, T.R., 2009. Strategy for Extracting DNA from Clay Soil and Detecting a Specific Target Sequence via Selective Enrichment and Real-Time (Quantitative) PCR Amplification. Applied and Environmental Microbiology 75, 6017-6021. 
Zolitschka, B., Behre K-E., Scheider, J., 2003. Human and climatic impact on the environment as derived from colluvial, fluvial and lacustrine archives-examples from the Bronze Age to the Migration period, Germany. Quaternary Science Review 22, 81-100. 
Table S1: Selected European River Etymology - FRANCE

\begin{tabular}{|c|c|c|c|}
\hline Name & Etymology & Meaning & Reference (where present) \\
\hline Aude & Atacos-(Ga) & Spirited, very fast & Delamarre 2003 \\
\hline $\begin{array}{l}\text { Bèbre } \\
\text { Beuvron } \\
\text { Bibiche } \\
\text { Bièvre } \\
\text { Bièvre }\end{array}$ & Bebros (Castor) & Beaver & Toponymie Rivieres de France 2002 \\
\hline Isère & isərós-(IE) & Impetuous, quick, vigorous & Delamarre 2003, Roussel 2009 \\
\hline $\begin{array}{l}\text { Loire } \\
\text { Loir } \\
\text { Loiret } \\
\text { Ligoure }\end{array}$ & Liger-(L) from Liga(Ga) & Silt, mud, alluvium & Montclos 1997 \\
\hline $\begin{array}{l}\text { Méouge } \\
\text { Meuse } \\
\text { Meuzin } \\
\text { Moselle } \\
\text { Moselotte } \\
\text { Mouge } \\
\end{array}$ & Mod- (mud) & Muddy & Toponymie Rivieres de France 2002 \\
\hline Orne & Olīnā-(C) & Elbow & Delamarre 2003 \\
\hline Rhine & Rēnos(Ga), Reinos, rei-(IE) & To move, flow, run & OED 2001 \\
\hline Rhône & $\begin{array}{l}\text { Renos, Rodonos or Rotonos(Ga), ret-(IE) and } \\
\text { danu- }\end{array}$ & Bold and proud & Toponymie Rivieres de France 2002 \\
\hline Seine & Sequana (L) & River Goddess & Ellis 1998 \\
\hline
\end{tabular}

Key: C-Celtic, L-Latin, F-French, IE-Indo-European, Ga-Gaulish 
Selected European River Etymology - IRELAND

\begin{tabular}{|c|c|c|c|}
\hline Name & Etymology & Meaning & Reference (where present) \\
\hline Shannon & Sionna(C) & River Goddess & \\
\hline Bann & An Bhanna(C) & River Goddess & Ó Mainnín 1992, Muhr, K. 1996 \\
\hline Nore & possibly referring to féar $(\mathrm{C})$ & Grass & Ó Cíobháin 2007 \\
\hline Liffey & An Ruirthech(Ga) & Fast, strong runner & \\
\hline Loobagh & An Lúbach(C) & Twisted one & \\
\hline Cladagh & an Chlaideach(C) & Washing river & Muhr 1999 \\
\hline Lyreen & Laidhrín(C) is diminutive of ladhar(C) & Forked & \\
\hline Quoile & An Caol(C) & Narrow & \\
\hline Shimna & Simhné(C) & River of bulrushes & Joyce 1910, Evans 1967 \\
\hline Tolka (Tolga) & An Tulcha(C) & The Flood & The Dublin Penny Journal 1834 \\
\hline
\end{tabular}

Key: C-Celtic, L-Latin, F-French, IE-Indo-European, Ga-Gaulish 


\begin{tabular}{|l|l|l|l|}
\hline Name & Etymology & Meaning & Reference (where present) \\
\hline Vistula & ueis-(IE) & to ooze, flow slowly & Adams 1997 \\
\hline Danube & Istros ('lotpoc)(Gr) & Strong, swift & Katičić, R. 1976 \\
\hline Kammel & kamb or camb(C) & Crooked & As River Camel (Cornwall) see Weatherhill 1995 \\
\hline Aar (Lahn) & Aar(PreG) & quick-flowing water & Krahe 1964 \\
\hline Nahe & Nava(L) from (C) & Wild River & Lott 2002 \\
\hline Kocher & Cochan(C) & winding, meandering & \\
\hline Schutter (Kinzig) & Scutro(EG), sceud(IG) & fast flowing water & \\
\hline Wutach & Wut(G), ach(C) & furious water & \\
\hline Innerste & oid(IG) & turbulent, strong & Blume 2005 \\
\hline Oker & ov and akara & upper, onward rushing & Blume 2005 \\
\hline Ecker & akara & onward rushing & \\
\hline Schunter & Sukatora(S) & with many angles & \\
\hline Spree & sprejen, sprewen(G) or spreizen(G) & to spray water or spread & \\
\hline Wipper (Saale) & uipparaha(EG) & singing, bouncing river & \\
\hline $\begin{array}{l}\text { Elster (White \& } \\
\text { Black) }\end{array}$ & alstrawa(S) & hurrying & \\
\hline Unstrut & Strödu(EG) & boggy thicket & \\
\hline
\end{tabular}

Key: C-Celtic, L-Latin, F-French, IE-Indo-European, Ga-Gaulish, Gr-Greek, PreG-Pre German, EG-Early German, IG-Indo-Germanic, G-German, S-Slavic 
Selected European River Etymology - POLAND

\begin{tabular}{|l|l|l|l|}
\hline Name & Etymology & Meaning & Reference (where present) \\
\hline Jizera & Possibly -eis & to move forward, race violently & \\
\hline Narew & $-n r(I E)$ & water & Witold 1999 \\
\hline Poprad & pręd-(PS) and priast'(S) & to flow fast, to jump and to spin & Ondruš 1991 \\
\hline
\end{tabular}

Key: C-Celtic, L-Latin, F-French, IE-Indo-European, Ga-Gaulish, Gr-Greek, PreG-Pre German, EG-Early German, IG-Indo-Germanic, G-German, S-Slavic, PS-

Proto-Slavic 


\section{Selected European River Etymology References}

Adams, D.Q. 1997 'Encyclopedia of Indo-European Culture'. London: Fitzroy-Dearborn, 207.

Blume, H. 2005. 'Oker, Schunter, Wabe'. Braunschweigisches Jahrbuch für Landesgeschichte, vol. 86.

Delamarre, Xavier 2003. 'Dictionnaire de la langue gauloise : une approche linguistique du vieux-celtique continental'. Collection des Hespérides (Revised and augmented 2 nd ed.). Paris: France.

Ellis, P.B. 1998 'The Ancient World of the Celts' Constable.

Evans, E. 1967 'Mourne Place-names, Mourne Country: Landscape and Life in South Down', 231-5. Belfast.

Joyce, P.W 1910. 'The origin and history of Irish names of places', Volume II. London Longmans, Green

Katičić, R. 1976 'Ancient Languages of the Balkans, Part One'. Paris: Mouton, 144.

Krahe, H. 1964. 'Unsere ältesten Flussnamen' [Our oldest river names]. Wiesbaden.

Lott, B.H. 2002. 'Der Kocher von der Quelle bis zur Mündung'. Swiridoff Verlag, Künzelsau.

Mills, A.D. 2003, A Dictionary of British Place-Names, Oxford University Press.

Montclos, Jean-Marie Pérouse de 1997 'Châteaux of the Loire Valley'. Könemann.

Muhr, K. 1996. 'Place-Names of Northern Ireland' vol. 6 p. 322-3

Muhr, K. 1999 'Celebrating Ulster's Townlands' Ulster Place-Name Society Northern Ireland Place-Name Project, QUB, Belfast.

Ó Cíobháin, B. 2007. "The River Nore - An Fheoir", Old Kilkenny Review, Kilkenny Archaeological Society. 59: 69-70.

Ó Mainnín, M. 1992. 'Place-Names of Northern Ireland' vol. 3 p. 175-7

OED Online Etymological Dictionary 2001

Ondruš, Š. 1991. 'Ešte raz o pôvode tatranskej rieky Poprad'. Slovenská reč. Bratislava: Veda, Vydavatel'stvo Slovenskej akadémie vied (4).

Roussel, G. 2009 'Encyclopédie de l'Arbre Celtique' 
The Dublin Penny Journal 1834 'A Day's Ramble on the North Side of the City', Vol. 2, No. 87 (Mar. 1, 1834), pp. 273-275

Toponymie Rivieres de France 2002 'Quelques origines de noms de rivières' [website] http://crehangec.free.fr/rivac.htm\#a accessed 20.01.18 Weatherhill, C. 1995. 'Cornish Place Names and Language'. Sigma Leisure.

Witold, M. 1999. 'Wieża Babel'. Wrocław: Zakład Narodowy im. Ossolińskich. 